\title{
25 Research Square \\ Identification and Validation of Novel Endogenous Controls for qPCR Normalization in SK-BR-3 Breast Cancer Cell Line
}

\section{Ingrida Mitre \\ Rigas Stradinas Universitate \\ Dina Nitisa \\ Rigas Stradinas Universitate \\ Valdis Pirsko \\ Rigas Stradinas Universitate \\ Inese Cakstina \\ Rigas Stradinas Universitate}

Nityanand Jain ( $\nabla$ nityapkl@gmail.com )

Rigas Stradinas Universitate https://orcid.org/0000-0002-7918-7909

\section{Research}

Keywords: SK-BR-3, RT-qPCR, reference genes, hypoxia, gene expression, breast cancer cell line, HER2 enriched

Posted Date: July 15th, 2021

DOl: https://doi.org/10.21203/rs.3.rs-689871/v1

License: (c) (i) This work is licensed under a Creative Commons Attribution 4.0 International License. Read Full License 


\section{Abstract}

Background: Normalization of gene expression using internal controls or reference genes (RGs) has been the method of choice for overcoming and standardizing the technical variations in reverse transcription quantitative polymerase chain reactions (RT-qPCR). Conventionally, ACTB and GAPDH have been used as reference genes despite evidence from literature discouraging their use, especially as single internal controls. Hence, it becomes crucial to identify suitable controls. In the present study we identified and investigated novel reference genes in SK-BR-3, an HER2-enriched breast cancer cell line. To identify novel candidate reference genes, we compiled and analyzed transcriptomic data from 82 HER2-E breast cancer samples from TCGA (The Cancer Genome Atlas) database. Twelve genes with relatively stable expression were selected for further analysis. Additionally, 13 RGs from literature were selected for analysis. The expression variations of the candidate genes in SK-BR-3 were studied over five successive passages ( $p$ ) in two parallel cultures S1 and S2 and in acute and chronic hypoxia using various algorithms. Finally, the most stable RGs were selected and validated for normalization of the expression of three genes of interest (GOIs) in normoxia and hypoxia using Pfaffl's method.

Results: HSP90AB1, DAD1, PFN1, RPL13A and PUM1 were the top five most stable RGs in the SK-BR-3 cell line. However, upon normalization of the GOIs, RPL13A was not a suitable RG candidate. Although geNorm suggests use of two reference genes, as a good practice, we investigated the reference genes in triplets. Accordingly, after normalization of GOls in hypoxia, we found that the remaining four genes when used in triplets (in any combination) successfully normalized the experimental variations in RT-qPCR experiments.

Conclusions: HSP90AB1, DAD1, PFN1 and PUM1 can be used in any combination of three (triplets) for optimizing intra- and inter-assay gene expression differences in the SK-BR-3 cell line. Additionally, we discourage use of conventional RGs (ACTB, GAPDH, RPL13A, RNA18S and RNA28S) as internal controls for RT-qPCR in SK-BR-3 cell line.

\section{Background}

Reverse Transcription quantitative Polymerase Chain Reaction (RT-qPCR) represents a modified variant of the popular conventional PCR with diverse applications, ranging from different areas in functional genomics to molecular medicine, virology, microbiology, and biotechnology [1]. Quantitative PCR-based assays can target both DNA (genome) and RNA (transcriptome), thereby making it an extremely powerful and important technique in molecular diagnostics [2]. While functional genomics deals with understanding the functions and interactions of genes and proteins at a genome-wide level including the role of ligands, receptors, and signaling networks that converge on transcriptional regulation, transcriptomic analysis, on the other hand, deals with ascertaining the functional significance to expression signature changes between tissues, disease states, or treatment [2]. Large-scale analysis of expression patterns is performed by RNA-Seq or highthroughput microarray analysis, however, the findings for individual genes usually are validated by RT-qPCR due to its high sensitivity, specificity, reproducibility, and broad dynamic range [2-4].

However, this enhanced sensitivity of RT-qPCR imposes special conditions. The protocol necessitates accurate and precise pipetting, high-quality RNA, accurate estimation of RNA concentration, and efficient 
reverse transcription [3]. Other considerations include standardization of RT-qPCR protocols [5], maintaining consistency of used reagents [6-7] and careful attention towards assay design, template preparation, and statistical analysis [8]. Any deviation from these requirements (by human error etc.) can introduce variations and influence the accuracy and precision of the results [9-12]. To overcome and account for such deviations, several strategies are recommended that can be incorporated in the protocol at different stages [12-14] ranging from ensuring that a similar sample size is chosen, to using controls like spike-in foreign RNA and reference genes (previously housekeeping genes).

Normalization using reference genes has been the method of choice by most researchers since variations in the experimental workflow will affect all genes similarly [14-16]. The expression of reference genes is expected to be sufficient and stable across different tissues and cell lines under varied experimental conditions [17]. However, variance in the expression of conventional reference genes like ACTB and GAPDH across different cell types has been noted [18-22] causing a continued search for suitable candidate genes. In addition, given the highly specific nature of RT-qPCR, the Minimum Information for Publication of Quantitative RT-PCR Experiments (MIQE) guidelines recommend to use more than one reference gene for normalization unless a clear evidence of uniform expression dynamics of the single reference gene is reported for specific experimental conditions [11]. Identification and validation of novel reference genes, hence, becomes imperative for accurate normalization. In the past reference genes have been identified using various large-scale gene expression profiling methods such as Expressed Sequence Tags (ESTs), Serial Analysis of Gene Expression (SAGE) and Microarray Analysis [23-25]. However, with the advent in technology, better techniques using RNA-seq data have been employed to identify stable reference genes. Several studies have previously identified novel reference genes and/or validated conventional reference genes for the study of breast cancer in general or of molecular subtypes [26-38].

Breast cancer represents the most common malignant disease worldwide among women, accounting for $24 \%$ of new cancer cases and $15 \%$ of cancer related deaths in 2018 [39] with the number predicted to almost double to $46 \%$ by 2040 [40]. With the immense burden of the disease, it becomes crucial to develop better protocols, prediction tools, diagnostics, and treatment modalities. The PAM50 (Prediction Analysis for Microarrays) represents a 50 gene classifier containing mostly hormone receptor, proliferation related, myoepithelial and basal feature related genes and is widely used to classify breast cancer into molecular subtypes [41-43]. The HER2-Enriched (HER2-E) subtype according to PAM50 is defined by higher expression of ERBB2 along with upregulated expression of tumor proliferation related genes at the RNA and protein levels in comparison to other cancer types [44-45]. SK-BR-3, established in 1970 from the pleural effusion of a Caucasian female with malignant breast adenocarcinoma, is a human breast cancer cell line overexpressing ERBB2 gene product [46]. There are contrasting views in the literature over the classification of SK-BR-3 with some authors including it in the luminal subtype [47-48], while others classifying it as HER2$E[49-51]$.

In the present study, we identified and validated novel reference genes that could be used to normalize qPCR data in SK-BR-3 breast cancer cell line. Additionally, we compared the gene expression stability of newly identified genes with previously reported reference genes [26-38] to select suitable candidate reference genes. Our study reports for the first time to our knowledge, a comprehensive analysis, combining previous 
and novel candidates studied over multiple successive passages (p), in replicate cultures S1 and S2, and validated in various hypoxic conditions for SK-BR-3 cell line.

\section{Materials And Methods}

\subsection{TCGA transcriptomic analysis for selection of novel candidate reference genes}

The transcriptome profiling datasets of 82 HER2-E (PAM50 classifier) breast cancer samples were downloaded from TCGA-BRCA legacy archive via R package TCGAbiolinks [52-54]. The scaled_estimate (Platform - Illumina HiSeq; file extension - rsem.genes.results) values, which represent the estimated frequency of gene/transcripts amongst the total number of transcripts that were sequenced, were obtained from the database. TPM (transcripts per million) values were generated by multiplying scaled_estimate values to a factor of 1 million $\left(10^{6}\right)$. For data analysis and visualization, the TPM values were converted to logarithmic scale using log2(TPM).

\subsection{Gene Ontology (GO)}

GO Annotations and enrichment analysis was done using a web based open-access tool - The Gene Ontology Resource, powered by Panther Classification (http://geneontology.org/) [55-58]. Gene ranking was based on the fold enrichment against the background frequency of total genes annotated to that term in the designated species (Homo Sapiens; whole genome, GO version Oct 2020, doi: 10.5281/zenodo.4081749) [59]. Fisher's Exact test with False Discovery Rate (FDR) correction was used to estimate significance with the cut-off FDR value of $<0.05$. The tool was further used to group genes based on functional classification.

\subsection{Culture and seeding conditions}

Samples were collected from the SK-BR-3 cell line (ATCC, HTB-30) that had been used in our laboratory for previous studies [60]. For consecutive passage analysis, two cultures S1 and S2 were established from different laboratory lineages of SK-BR-3 which were cultured over five consecutive passages (p7-p11). For hypoxic exposure analysis, cultures at the level of $80-90 \%$ confluence were transferred to Xvivo System Sx2 (BioSpherix Medical; $37^{\circ} \mathrm{C}, 5 \% \mathrm{CO}_{2}, 2 \% \mathrm{O}_{2}$ ). The length of hypoxic exposure for acute hypoxia samples was $24 \mathrm{~h}$ and $72 \mathrm{~h}$. To obtain chronic hypoxia samples, the cultures $(\mathrm{n}=3)$ were fully maintained in the hypoxic environment for four consecutive passages.

From each culture, 3 lysates (in triplicates) were collected per passage. Cells were cultured in RPMI-1640 (Lonza, BE12-115F), supplemented with 10\% FBS (fetal bovine serum; Sigma Aldrich, F9665) at $37^{\circ} \mathrm{C}, 5 \% \mathrm{CO}_{2}$ with the growth medium replaced every 2-3 days. Cell passaging was performed using 1x TrypLE solution (Thermo Fisher Scientific, A12177-02). Cells were grown to $80-100 \%$ confluence in T-25 $\mathrm{cm}^{2}$ flasks (Sarstedt). Cell count and viability was estimated using a cell counting chamber (Improved Neubauer Hemocytometer). For further consecutive passages, cells were seeded at a density of 5000 cells $/ \mathrm{cm}^{2}$. Three TRIzol lysates $\left(1 \times 10^{6}\right.$ cells) were obtained from each passage for both cultures for RNA isolation.

\subsection{RNA extraction and cDNA synthesis}


Total RNA was extracted using Trizol reagent (Thermo Fisher Scientific, 15596026) according to the manufacturer's protocol. The concentration and quality of the RNA was assessed by Nanodrop 2000 with the mean absorption ratios A260/280 and A260/230 checked to ensure RNA purity. RNA integrity was evaluated using $1.8 \%$ agarose gel electrophoresis. The RNA was further examined for DNA contamination by PCR for $A C T B$ and GAPDH. The PCR reaction was performed in the presence of both positive and negative controls. No amplified PCR product was found on the agarose gel after PCR and electrophoresis of the RNA samples (except for positive controls). The cDNA synthesis reaction was carried out using the High-Capacity cDNA Reverse transcription kit (Thermo Fisher Scientific, 4368814) in accordance with the manufacturer's protocol and guidelines and was stored at $-20^{\circ} \mathrm{C}$ until further analysis.

\subsection{Selection of reference genes and primer design}

In total, 13 reference genes were selected by searching for relevant literature related to various breast cancer cell lines [26-38]. Twelve more genes were selected from the TCGA dataset analysis and were referred to as Novel Candidate Reference genes. All selected genes are summarized in Table 1. Along with these 25 candidate reference genes, three genes of interest (target genes; GOIs) were also normalized to test the selected reference genes (Table 1). Primers for all 12 selected novel candidate reference genes, PPIA and SNAI1 were designed using Primer3Plus, in accordance with the MIQE guidelines $[11,61]$ while the rest were taken from literature or from our previous study in MCF-7 cell line [62]. The gene function, primer pairs and respective melting curves of all the selected genes are presented in Additional File 1.

Table 1

Summary table of candidate reference genes and genes of interest (GOI)

\begin{tabular}{|c|c|c|}
\hline Cell Line & Source & Selected Candidate Reference Genes \\
\hline $\begin{array}{l}\text { Breast } \\
\text { Cancer } \\
\text { various cell } \\
\text { lines }\end{array}$ & Literature & $\begin{array}{l}\text { ACTB [26, 29, 32, 34], CCSER2 [35], GAPDH[34], HNRNPL [37], HSP9OAB1 } \\
{[31], P C B P 1[37], P G K 1[30], P P I A[36], P U M 1[28,33,35], R N A 18 S[26,34],} \\
R N A 28 S[62], R P L 13 A[27,33], S F 3 A 1[32,38]\end{array}$ \\
\hline HER2-E & $\begin{array}{l}\text { TCGA } \\
\text { (Novel) }\end{array}$ & $\begin{array}{l}\text { BSG, CFL 1, DAD1, EIF5A, GABARAP, NACA, PFN1, PSMB4, RBX1, TPT1, } \\
\text { TUBA1B, UBC }\end{array}$ \\
\hline $\begin{array}{l}\text { Genes of } \\
\text { Interest } \\
\text { (GOI) }\end{array}$ & $\begin{array}{l}\text { Expression } \\
\text { Atlas }\end{array}$ & AURKA, BUB1, SNAI1 \\
\hline
\end{tabular}

Selection of the three genes of interest was based on the data from Expression atlas (https://www.ebi.ac.uk/gxa/home; European Bioinformatics Institute). The atlas was searched for SK-BR-3 cell line and GOls were randomly selected based on high expression (AURKA; 241 TPM), medium expression (BUB1; 31 TPM), and low expression (SNA17; 5 TPM).

\subsection{Primer efficiency}

Standard (calibration) curves were analyzed using different concentrations and dilutions as shown in Additional File 1. For each reaction, $7 \mu \mathrm{l}$ was used in a 384 well plate. Each dilution was done in triplicate for each primer pair along with appropriate non-template controls (NTC). Real-time PCR was performed using the ViiA7 RT-PCR thermocycler (Thermo Fisher Scientific). The cycling parameters were $95^{\circ} \mathrm{C}$ for $10 \mathrm{mins}$ 
followed by 40 cycles of amplification at $95^{\circ} \mathrm{C}$ for 15 seconds, $58^{\circ} \mathrm{C}$ for 30 seconds and $72^{\circ} \mathrm{C}$ for 30 seconds with signal acquisition. After that melting curve were obtained by signal acquisition from $58^{\circ} \mathrm{C}$ to $95^{\circ} \mathrm{C}$ in increments of $0.05^{\circ} \mathrm{C} / \mathrm{s}$.

\subsection{Reverse transcription quantitative PCR (RT-qPCR)}

Reverse transcription quantitative PCR (RT-qPCR) was performed with $10 \mathrm{ng}$ of cDNA per reaction using ViiA 7 RT-PCR thermocycler (Thermo Fisher Scientific). Triplicate reactions of each sample were done using HOT FIREPol EvaGreen qPCR Supermix (Solis Biodyne, 08-36-00020) on 384 well plates (Applied Biosystems ${ }^{\text {TM }}$, LS4309849). The cycling parameters were $95^{\circ} \mathrm{C}$ for 10 mins followed by 40 cycles of amplification at $95^{\circ} \mathrm{C}$ for 15 seconds, $58^{\circ} \mathrm{C}$ for 30 seconds and $72^{\circ} \mathrm{C}$ for 30 seconds. This was followed by melting curve acquisition as described above. All assays were performed with non-template controls (NTC).

\subsection{Determination of the least variable reference genes, validation in hypoxic conditions \& statistical analysis}

The $\mathrm{Cq}$ values obtained from RT-qPCR were used to determine the stability of the candidate reference genes in the sequential normoxic passage samples using different algorithms (coefficient of variation - CV\%, NormFinder [63], geNorm [17], BestKeeper [64], Comparative $\Delta \mathrm{Ct}$ [65] and RefFinder [66]). The least variable reference genes were then tested in hypoxic samples to verify their stability and expression in hypoxic conditions. The endpoints for each of these algorithms are listed in Appendix 1. Data management and storage along with descriptive statistics were done using MS Excel (Microsoft Office 365). The statistical analysis was done using SPSS v27.0 (Released 2020, IBM Corp., Armonk, NY, USA) and R v4.0.2 (via R studio v1.3.1056).

\section{Results}

\subsection{TCGA analysis for selection of novel reference genes}

Novel candidate reference genes were selected on the basis of HER-E breast cancer sample transcriptomic data from TCGA legacy dataset by applying the following criteria: (I) medium to high expression levels mean $[\log 2(T P M)] \geq 5$; (II) low expression variance - standard deviation [log2(TPM)] $\leq 1$; (III) no exceptional expression - no log2 (TPM) differs from the mean log2 (TPM) by a factor of two or more (criteria based on study by Li Y. et al., doi: 10.1186/s12864-019-5661-x). Once the genes were filtered according to the criteria, CV\% (Coefficient of Variation) was calculated. The lower the CV\%, the more stable the expression of a candidate reference gene.

A complete list of 3363 ranked genes which fulfilled the selection criteria is available in Appendix 2. The candidates for validation (12 genes) were selected, based on further criteria including association with dissimilar cellular functions and lack of association/close relation to traditional reference genes considered. Upon consideration, from the top 10 genes, six genes were selected (GABARAP, PFN1, UBC, EIF5A, CFL 1 and TPT1). Three more genes were selected from ranks 11-20 (NACA, DAD1 and PSMB4). Finally, three genes ( $T U B A 1 B, R B X 1$ and $B S G$ ) were selected from the top 400 ranks randomly. 
Based on expression levels (measured as log2[TPM]), ACTB, TPT1 and GAPDH showed high expression levels while PUM1, SF3A1 and PPIA showed low expression levels in HER2-E samples (Fig. 1a). Based on CV\%, however, GABARAP, ACTB and PFN1 were the genes with the least variable expression, while PUM1, $S F 3 A 1$ and $P G K 1$ were the genes with the most variable expression (Fig. 1b). Genes with higher levels of expression generally were associated with lower inter-sample variation.

\subsection{Gene Ontology (GO) over-representation analysis}

Based on fold enrichment (Table 2), the top ranked biological process was modulation by symbiont of the host process which included GAPDH, UBC and PGK1. However, the most significantly enriched biological process was cellular response to cytokine stimulus (FDR = 3.33E-03) which included GAPDH, RBX1, TUBA1B, HSP90AB1, RPL13A, UBC, CFL 1, PPIA and PSMB4. A complete ontology for Molecular function and Cellular Component is presented in Additional File 2. 
Table 2

Gene Ontology (Biological Process) of candidate reference genes ranked by fold enrichment

\begin{tabular}{|c|c|c|c|c|c|}
\hline GO ID & GO Term & $\begin{array}{l}\text { No. of } \\
\text { genes* }\end{array}$ & $\begin{array}{l}\text { Fold } \\
\text { Enrichment }\end{array}$ & $\begin{array}{l}\text { Raw } \\
\mathrm{P} \\
\text { value }\end{array}$ & FDR \\
\hline GO:0044003 & Modulation by symbiont of host process & 3 & 46.10 & $\begin{array}{l}4.24 \mathrm{E}- \\
05\end{array}$ & $\begin{array}{l}3.05 \mathrm{E}- \\
02\end{array}$ \\
\hline GO:0006090 & Pyruvate metabolic process & 3 & 38.31 & $\begin{array}{l}7.20 \mathrm{E}- \\
05\end{array}$ & $\begin{array}{l}3.68 \mathrm{E}- \\
02\end{array}$ \\
\hline GO:0061418 & $\begin{array}{l}\text { Regulation of transcription from RNA } \\
\text { polymerase Il promoter in response to } \\
\text { hypoxia }\end{array}$ & 3 & 34.87 & $\begin{array}{l}9.43 \mathrm{E}- \\
05\end{array}$ & $\begin{array}{l}4.27 \mathrm{E}- \\
02\end{array}$ \\
\hline GO:0048524 & Positive regulation of viral process & 3 & 32.67 & $\begin{array}{l}7.14 \mathrm{E}- \\
06\end{array}$ & $\begin{array}{l}1.03 \mathrm{E}- \\
02\end{array}$ \\
\hline GO:0019058 & Viral life cycle & 5 & 20.33 & $\begin{array}{l}4.26 \mathrm{E}- \\
06\end{array}$ & $\begin{array}{l}7.52 \mathrm{E}- \\
03\end{array}$ \\
\hline GO:0006417 & Regulation of translation & 5 & 12.12 & $\begin{array}{l}4.90 \mathrm{E}- \\
05\end{array}$ & $\begin{array}{l}3.26 \mathrm{E}- \\
02\end{array}$ \\
\hline GO:0071345 & Cellular response to cytokine stimulus & 9 & 7.86 & $\begin{array}{l}8.38 \mathrm{E}- \\
07\end{array}$ & $\begin{array}{l}3.33 \mathrm{E}- \\
03\end{array}$ \\
\hline GO:0043066 & Negative regulation of apoptotic process & 7 & 6.96 & $\begin{array}{l}4.13 \mathrm{E}- \\
05\end{array}$ & $\begin{array}{l}3.12 \mathrm{E}- \\
02\end{array}$ \\
\hline GO:0006139 & $\begin{array}{l}\text { Nucleobase containing compound metabolic } \\
\text { process }\end{array}$ & 11 & 3.64 & $\begin{array}{l}6.05 \mathrm{E}- \\
05\end{array}$ & $\begin{array}{l}3.56 \mathrm{E}- \\
02\end{array}$ \\
\hline GO:0010604 & $\begin{array}{l}\text { Positive regulation of macromolecule } \\
\text { metabolic process }\end{array}$ & 12 & 3.05 & $\begin{array}{l}1.33 \mathrm{E}- \\
04\end{array}$ & $\begin{array}{l}5.02 \mathrm{E}- \\
02\end{array}$ \\
\hline GO:0043170 & Macromolecule metabolic process & 17 & 2.43 & $\begin{array}{l}2.16 \mathrm{E}- \\
05\end{array}$ & $\begin{array}{l}2.01 \mathrm{E}- \\
02\end{array}$ \\
\hline
\end{tabular}

\subsection{Grouping of genes based on functional classification (Panther)}

Panther was used to group the candidate reference genes based on function. The grouping was done across five different ontologies (Fig. 2) - GO biological process, GO molecular function, GO cellular component, protein class and pathway. Most of the genes in $\mathrm{GO}$ cellular component analysis were associated with cell or cell part (17 genes each) (Fig. 2). In protein class classification six genes were identified as genes encoding cytoskeletal proteins (ACTB, TUBA1B, TPT1, PFN1, CFL1 and GABARAP). Finally, based on pathway, three genes were associated with cytoskeletal regulation by Rho GTPase pathway (ACTB, PFN1 and CFL 1) while two genes were associated each with glycolysis (GAPDH and $P G K 1)$ and Huntington disease (GAPDH and $A C T B)$. 


\subsection{Candidate reference gene stability in SK-BR-3 cell line}

In the present study, we collected three technical replicates from five consecutive passages (p7-p11) in two replicate cultures S1 and S2. The biological replicates were analyzed for all 25 candidate reference genes, thereby producing a dataset with $250 \mathrm{Cq}$ values. A similar dataset was analyzed for the three genes of interest (dataset of $30 \mathrm{Cq}$ values). Different algorithms were then used to analyze the stability of the reference gene expression. NormFinder, geNorm, comparative $\triangle \mathrm{Ct}$ and RefFinder all ranked HSP90AB1, $P G K 1, D A D 1$, PUM1 and RPL13A as the most stable genes in the consecutive passages of SK-BR-3 (Fig. 3). BestKeeper, however, ranked RBX1,CFL 1 and UBC as the most stable genes. RNA18S, TUBA1B and RNA28S were consistently ranked as the least stable reference gene candidates by all algorithms.

\subsection{Candidate reference gene stability in replicate cultures}

To analyze the expression stability of candidate reference genes in replicate cultures S1 and S2, we applied all algorithms separately, as shown in Additional File 3. Descriptive analysis revealed that CCSER2 and GABARAP showed low expression levels $(\mathrm{Cq}>28)$, while RNA28S and RNA18S showed high expression levels $(\mathrm{Cq}<15)$. Coefficient of variation $(\mathrm{CV} \%)$ analyses revealed that $T U B A 1 B$ showed high variation $(>50 \%)$ and hence was not a suitable candidate. Further analysis with BestKeeper revealed ACTB, SF3A1, CFL 1, UBC and $N A C A$ to have a low/moderate correlation with the BestKeeper Index (BI). After removal of these 10 candidate reference genes, the remaining 15 genes were re-analyzed using various algorithms, and none of the remaining genes violated any criteria. Finally, cumulative rankings from both cultures revealed HSP $90 A B 1$, $D A D 1, P G K 1, R P L 13 A$ and $P U M 1$ to be the top 5 most stable genes.

\subsection{Selection of reference genes for further validation}

Since geNorm indicated that use of two genes (Additional File 3) would be sufficient, we decided to select the top five least variable genes from our analysis and test different triplets (rather than in pairs, as a good practice) of the selected five genes. To select the genes, we analyzed the results obtained so far from both cultures whilst also factoring-in CV\% rankings (Additional File 3). As a result, HSP90AB1, DAD1, PFN1, RPL 13A and PUM1 were selected for further analysis and normalization of the genes of interest.

\subsection{Normalization of genes of interest (GOls)}

The $\Delta \Delta$ Ct method is the method of choice for normalization of gene expression of genes of interest [67]. The modification of the $\Delta \Delta \mathrm{Ct}$ method, accounting for primer efficiencies and multiple reference genes [68-69] was used in the present study. To account for primer efficiency in the equation, the mean efficiency from broad range and narrow range dilutions was used. Accordingly, we normalized three genes of interest (GOls) - AURKA, BUB1 and SNAI1 - with triplet pairs of the five chosen reference genes (10 possible triplets as shown in Fig. 4). According to the guidelines, any arbitrary sample can be considered as an internal calibrator (control) for normalization without any effects on the relative quantification result. Hence, we considered passage $\mathrm{p} 7$ as the internal calibrator since it was the initial passage in the experiment.

For evaluation of successful normalization, the NRQs (normalized relative quantities) should be checked for patterns in expression, and the difference should be minimal between each sample after normalization [69, 
70]. For $A U R K A$, we noticed that the expression in comparison with $\mathrm{p} 7$ decreased in $\mathrm{p} 8$ followed by increase in p9. The NRQs were found to be close to p7 levels in p10 and p11 (Fig. 4a). However, this trend was not observed in the triplets with RPL $13 A$ (triplets $2,5,6,7,9$ and 10). The expression of triplets with RPL 13A in p9 and p10 was highly elevated in comparison to p7 (Fig. 4a). Similar observations were made for $B U B 1$ and SNAI1 (Fig. 4b and 4c). This may be explained by the fact that among the five selected genes RPL 13A had the lowest correlation $r(r=0.856)$ with the BestKeeper Index (Additional Table 10 in Additional File 3), which was also shown by NormFinder results. Hence, RPL 13A was not an ideal candidate and we removed it from the further analysis.

\subsection{Effects of hypoxia on the expression of the selected reference genes}

To evaluate the effects of hypoxia on reference gene stabilities, we applied all algorithms combining data with hypoxic sample results for the four reference genes (HSP90AB1, PUM1, DAD1 and PFN1). In hypoxia, $D A D 1$ and $H S P 90 A B 1$ were the two most stable genes as revealed by NormFinder, geNorm, Comparative $\triangle \mathrm{Ct}$

and RefFinder (Fig. 5). BestKeeper, however, ranked PUM1 as the most stable gene, and the DAD1 showed the highest correlation with the BestKeeper index.

Comparison of the expression stabilities of the genes in normoxia vs hypoxia showed that the expression stability of all four genes decreased after addition of hypoxic samples to the dataset (Fig. 5). Only DAD1 and PFN1 displayed improved expression stability in hypoxia according to RefFinder (Fig. 5f). Similarly, only these two genes improved their correlation with the BestKeeper index in hypoxia.

\subsection{Validation of reference genes in hypoxic conditions}

We found that after normalization AURKA was slightly upregulated (Fig. 6a) after $24 \mathrm{~h}$ of hypoxic exposure while after $72 \mathrm{~h}$, different triplets indicated different results. The normalization factor (NF) was within the acceptable limits ( $\mathrm{NF}<2$ to 3 -fold relative to the average), thus eliminating potential causative issues, e.g., starting material quantity or quality, or a problem with one of the reference genes (either not stably expressed, or not adequately measured) [70]. As pointed out by the other authors [34, 70], the choice of calibrator sample (reference genes) does not influence the relative quantification result.

Although numbers may differ, the actual fold differences between the samples remain identical, therefore the results are fully equivalent and only rescaled. The expression of $B U B 1$ was sequentially increasing, while SNAI1 after an initial (24 h) downregulation became upregulated, but still below the control levels (Fig. 6). Both AURKA, and BUB1 were downregulated (-0.78 and -1.26 average log2 fold change, respectively) in chronic hypoxia, when normalized by all four reference gene triplets (Fig. 6). However, SNA/1 was upregulated in chronic hypoxia (+1.03 average log2 fold change). Based on our analysis, we can conclude that the selected reference gene triplets were able to successfully normalize the genes of interest irrespective of the expression levels of gene of interest in SK-BR-3 cell line (AURKA - high expression; $B U B 1$ - medium expression; SNA/1 - low expression)

\section{Discussion}


A pivotal aspect in any gene expression study is the selection of appropriate internal controls that are expressed uniformly irrespective of culturing conditions, experimental treatment, nutrient stress etc. These controls (or references) normalize any variations in starting quantities, calibration issues or poor pipetting, thereby providing accurate results. However, complex gene-gene interactions and environmental effects on gene expression complicate identification of such controls. Another layer of complexity in this pursuit is added by intrinsic heterogeneity of the cancer cells. Several tools and algorithms (NormFinder, geNorm, BestKeeper, Comparative $\Delta \mathrm{Ct}$ and RefFinder) have been developed that can aid in sorting, selection, and validation of the reference genes. However, the considerations regarding applicability of these algorithms and the acceptable cut-off limits are often misinterpreted or misapplied. Finally, identification and extensive validation of the reference genes for each type of biological object in different conditions may not be feasible in every instance. Such studies are often time and resource (labor, financial) consuming. In the present study, we have identified and validated novel reference genes for normalization of RT-qPCR results in SK-BR-3 breast cancer cell line.

In the past the TCGA database has been commonly used to identify novel and reliable candidate genes in different cancer types [37-38], but it has never been investigated individually for HER2-E subtype of breast cancer. Our analysis of TCGA legacy data revealed that GABARAP, ACTB and PFN1 were the top three genes with the least variation amongst the samples (Fig. 1b). However, upon validation in the SK-BR-3 cell line, we found that the least variation amongst the samples was displayed by RBX1, UBC and CFL 1 (Additional File 3). These differences between TCGA database and RT-qPCR results are normal and expected. Firstly, the database represents a heterogenous mixture of similar subtypes while the SK-BR-3 is a single cell line, therefore constitutes a more homogenous sample. Secondly, all samples of TCGA repository come from primary untreated tumors collected from different institutes. Thirdly, there is an inherent possibility of bias in the biorepository generation process, stemming from different institutional research interests, operative protocols, or patient populations [71]. Also, it must be taken into account that tissue specimens (TCGA data) in addition to cancer and normal mammary cells contain various types of stromal and immune cells, which are absent from the cell culture samples. This type of heterogeneity also may have effects on the overall transcription levels and stability. The database accommodates for most of the possible gene expression variations in tissues (in vivo) and, since cell lines like SK-BR-3 have been under constant cultivation over longterm, they tend to behave like outliers when compared to the TCGA database. Nonetheless, such extrapolation, bridging and application of in vivo data to in vitro conditions enable us to find common core genes which are uniformly expressed in both scenarios.

Gene Ontology (GO) analysis (Table 2) revealed that the candidate genes selected based on the TCGA samples and literature were most significantly enriched in cellular response to cytokine stimulus (G0:0071345; CFL 1, GAPDH, HSP90AB1, PPIA, PSMB4, RBX1, RPL 13A, TUBA1B and UBC). Indeed, it is well known that breast cancer cells respond to various cytokines in their microenvironment. The cells have been shown to evade cytokines like TGF- $\beta$ in the early stages (due to its anti-proliferative effects), however, in the later stages TGF- $\beta$ stimulates the progression of the disease by induction of epithelial to mesenchymal transition (EMT type 3) [72-74]. IL-1 (adipokine) is known to increase the aromatase activity in SK-BR-3 cells, resulting in generation of bioactive estrogens and increased cellular proliferation [75]. Other cytokines like IL6, IL-19, IL-20, TGF-a, TNF-a, and IL-23 are also known to promote cancer progression [72]. Using data

Page 11/32 
available from Mouse Genome Informatics (MGl; http://www.informatics. jax.org/), CFL1 was associated with cellular response to IL-1, IL-6 and TNF, GAPDH and RPL 13A were associated with response to IFN- $\gamma$, while HSP90AB1 and TUBA1B were associated with the response to IL-4. Apart from cytokine response, the genes were found to be enriched in viral life cycle (G0:0019058; BSG, HSP90AB1, PCBP1, PPIA and UBC) and positive regulation of viral processes (G0:0048524; BSG, PFN1 and PPIA). Evidence of various virus-related DNAs like EBV (Epstein-Barr virus), HPV (Human Papillomavirus), BLV (bovine leukemia virus) and MMTV (Mouse mammary tumor virus) has been found in breast cancers [76-79]. In fact, Lawson et al., demonstrated presence of HPV associated pre-malignant koilocytes in normal and malignant breast tissues [80], indicating the oncogenic correlation between viruses and breast cancer and the possible explanation for the enrichment of virus associated pathways in SK-BR-3 cell line. Using data from MGI, we found that BSG was associated with positive regulation of viral entry into the host cell, while HSP90AB1 was associated with virion attachment to the host cell. On the other hand, PFN1 and PPIA were found to be associated with positive regulation of viral transcription and viral genome replication, respectively.

To understand the role of the four validated reference genes in metabolic processes, GO biological processes analysis in association with data from MGI were investigated. The genes were found to be associated with negative regulation of apoptosis (DAD1) and nucleobase containing compound metabolic process (Table 2). HSP90AB1 was found to be associated with positive regulation of activities of telomerase, phosphoprotein phosphatase and protein serine/threonine kinase. PFN1 was found to play a role in positive regulation of DNA metabolic processes and of transcription by RNA polymerase II, while PUM1 was associated with regulation of mRNA stability and production of miRNAs (microRNAs). Based on Molecular function, HSP90AB1 and PFN1 shared two common ontologies - RNA binding and Cytoskeletal protein binding (Additional File 2), both of which seemed to be downregulated in hypoxic conditions (for PFN1, fold change was 0.68 and 0.45 after 24 hours 72 hours of acute hypoxia, respectively, and 0.89 in chronic hypoxia). With respect to cellular component analysis the regulation of different genes (even from the same ontology) during hypoxia was divergent/unrelated. Whilst PUM1, HSP90AB1 and PFN1 shared two ontologies - nuclear and cytosol associated genes, the genes were differently regulated with PUM1 showing upregulation while other two showed downregulation in gene expression.

Our analysis revealed that the four reference genes (HSP90AB1, DAD1, PUM1 and PFN1), when used in any combination of three, successfully normalized the genes of interest ( $A U R K A, B U B 1$ and $S N A / 1)$ in both hypoxic and normoxic conditions over multiple passages. HSP90AB1, previously known as HSPCB, was first described as a candidate reference gene by Jacob et al. [31] in a variety of 25 different cancer cell lines. However, the only breast cancer line in that study was MCF-7 (Luminal A subtype). The gene has been included among the most stable reference genes in other tissues/organs, e.g., ovary, muscle tissue, adipose tissue etc. [81-82]. Heat Shock Proteins like HSP90AB1 have been previously shown to be downregulated in response to hypoxia in pig adipose-derived stromal/stem cells [83] as well as in human hepatocytes [84]. Such downregulation (fold expression change of 0.71 after 24 hours and 0.88 after 72 hours in acute hypoxia and 0.52 in chronic hypoxia) appeared to have an impact on the stability of the gene by marginally lowering the expression stability in hypoxic conditions (Fig. 5). 
$D A D 1$, a novel reference gene identified in the present study, is a small integral membrane protein of the oligosaccharyltransferase (OST) enzyme complex involved in the highly conserved asparagine-linked glycosylation of proteins in all eukaryotic cells [85]. The gene has been shown to be involved in apoptosis. Loss of DAD1 gene led to apoptosis in hamster cell lines and yeast cells [86-87]. In fact, DAD1 was preferentially expressed in hepatocellular carcinoma (HCC) and prostate cancer cells [88-89]. Hence, it has been postulated that high expression of DAD1 in HCC cells can activate OST and block apoptosis, thereby enhancing tumor cell survival [88]. We speculate a similar role of the gene in the SK-BR-3 breast cancer cell line that could explain its consistent and stable expression. In A431 epithelial carcinoma cells, DAD1 was upregulated in hypoxic conditions (by a fold change of 1.2) after exposure of 72 hours [90]. In our results, however, DAD1 was downregulated by 0.64 -fold change after exposure to acute hypoxia for 24 and 72 hours. The expression then increased and approached normoxia levels during chronic hypoxia (fold change 0.95). The differences in our results from those in A431 cells could be explained by the cardinal differences in background transcriptome and epigenome of A4321 and SK-BR-3 cells. Furthermore, there were differences in culturing conditions. While our cells were exposed to $2 \% \mathrm{O}_{2}$ in acute hypoxia, the A431 cells were exposed to $<0.1 \% \mathrm{O}_{2}[90]$. Our results suggest that SK-BR-3 cells after an initial shock phase quickly adapted to chronic hypoxic conditions and continued to express core genes in levels similar to normoxia. This is also supported by the fact that the expression stability of DAD1 improved in hypoxia, i.e., it was expressed even more stably after exposure to hypoxia.

PFN1, another novel reference gene identified in the present study, is often regarded as the founding member of its family constituting four profilin genes (PFN1, PFN2, PFN3 and PFN4). These genes have been associated with almost every aspect of cellular functions including proliferation, survival, motility, endocytosis, membrane trafficking, mRNA splicing as well as gene transcription [91-92]. The overexpression of PFN1 could negatively regulate cancer cell motility in breast cancer cells [93]. Additionally, it has been demonstrated that in triple negative breast cancer cell lines, overexpression of PFN1 suppresses AKT (serinethreonine kinase) activation via upregulation of PTEN (phosphatase and tensin homolog) [94], indicating the tumor-suppressive character of PFN1 gene. Similar observations have also been reported in pancreatic cancer cells [95]. These findings are of interest since the expression of PFN1 in the SK-BR-3 cell line seems to be uniform and stable despite its anti-tumorigenic nature. In fact, depletion of PFN1 in breast cancer cells has enabled hyper-migratory phenotype in vitro and enhanced hematogenous dissemination from primary tumor in vivo [96]. We can hypothesize that some downstream regulation is at play, which leads to decreased PFN1 protein levels in breast cancer cells despite rather uniform expression of the gene.

Finally, the fourth reference gene identified for the SK-BR-3 cell line, PUM1 has been previously described as a candidate reference gene in various cancers including breast cancers $[28,33,35]$. The gene has been associated with cancer cell growth, migration, and invasion [97]. In fact, amongst the four selected reference genes in our study, only PUM1 showed an increase in expression fold change in hypoxia. The fold change was 0.80 and 1.13 after 24 hours and 72 hours of acute hypoxia, respectively, and reached 1.56 in chronic hypoxia. These findings indicate the crucial role played by the gene in the maintenance of cellular functions in hypoxic conditions. Another candidate gene, $R P L 13 A$, has been previously described as a stable reference gene in breast cancers [27, 33]. The expression of RPL $13 A$ was quite stable in our analysis, however, it did not yield successful normalization of the genes of interest. 
Various other reference genes in the past have been described to be suitable reference genes in breast cancers including GAPDH, ACTB, PPIA and RNA28S/RNA18S [26, 29, 32, 34]. However, there is also contrary evidence suggesting against the use of these genes as references [18-22]. Use of GAPDH as a reference gene has long been a topic of debate. It is overexpressed in cervical, prostate, pancreatic and lung cancers, and it has been the least stable gene in multiple studies [29, 34, 98-99]. Similar concerns have been raised concerning use of $A C T B$ as a single internal control [28]. RNA18S and RNA28S have been reported previously to be stable reference gene candidates [34], however, concerns regarding absence of purified mRNA samples and their relatively high abundance compared to the target mRNAs have been reported [17]. Both RNA28S and $R N A 18 S$ were highly expressed (mean $\mathrm{Cq}=7-8$ ) in the present study and in our study of MCF-7 cell line [62]. Secondly, these two genes are not included in the TCGA database, which makes it difficult to compare their expression between in vivo and in vitro scenarios.

PPIA along with ACTB was found to be the most stable reference gene for basal type breast cancer cell lines in hypoxic and serum deprived conditions [36]. However, our analysis revealed that the expression of PPIA was moderately stable and ranked 9th in the combined analysis (Additional File 3). In our study of MCF-7 breast cancer cell line, we identified GAPDH-CCSER2-PCBP1 triplet as the most stable reference gene triplet which could be used to normalize the expression of genes of interest in various nutrient stress conditions [62]. However, the expression of CCSER2 was extremely variable in the present study. The gene did not reach the thresholds set for TCGA analysis, and the expression of the gene was low (mean $\mathrm{Cq}=27.4$ ). Hence, we eliminated it from our analysis in early stages. PCBP1 and GAPDH were among the top 15 most stable reference genes in our analysis (Additional File 3). Interestingly, GABARAP was identified to have the least variation (CV\%) among our novel candidate reference genes, however, the gene was associated with low expression and poor primer efficiency when confirmed by RT-qPCR (Additional Files 1 and 3).

Nonetheless, the results of the present study are constrained by some limitations. First, the expression stability of the reference genes was validated in vitro only. Second, these reference genes were tested in normoxic and hypoxic conditions only. Their use for normalization of expression in other conditions such as nutrient stress, drug treatment etc. remains to be validated. Finally, given the heterogeneous behavior of cancer cells, there is a need for inter-laboratory validation to further confirm our results. The major question that arises is how many more reference genes we need to identify. Rather, how many reference genes can we identify. Although a precise number will be difficult to predict, the estimates in normal human tissues (using ESTs) predict the numbers to be in the range of 3100 to 6900 genes [92], thereby making a plethora of reference genes still waiting to be identified and validated that could be more promising than the ones previously reported. However, we agree with other authors that rather than testing thousands of genes, we need to validate a panel of reference genes whose expression under varying conditions can be proven to be as minimally variable and as robust as possible [35]. Accordingly, based on our analysis, we suggest the use of HSP9OAB1, DAD1, PFN1 and PUM1 in any combination of three (triplet), thereby giving other researchers not one but four different combinations to choose from based on their individual experimental designs and needs.

\section{Conclusions}


Based on the results of the present study, we suggest the use of HSP9OAB1, DAD1, PFN1 and PUM1 in any combination of threes (triplet) for normalization of the expression of genes of interest in SK-BR-3 breast cancer cell line. The conventional RT-qPCR reference genes like ACTB, GAPDH, RPL13A, RNA18S, RNA28S, as well as CCSER 2 and GABARAP are not appropriate for use as reference genes in the SK-BR-3 cell line.

\section{List Of Abbreviations}




\begin{tabular}{|c|c|}
\hline HER2-E & HER2 enriched \\
\hline MCF-7 & Michigan Cancer Foundation - 7 \\
\hline RGs & Reference genes \\
\hline RT-PCR & Real time - polymerase chain reaction \\
\hline $\mathrm{p}$ & Passage \\
\hline GOI & Gene of Interest \\
\hline $\mathrm{CV} \%$ & Coefficient of Variation \% \\
\hline S.D. & Standard Deviation \\
\hline TPM & Transcripts per Million \\
\hline BRCA & Breast Invasive Carcinoma \\
\hline TCGA & The Cancer Genome Atlas \\
\hline HUGO & Human Genome Organization \\
\hline FBS & Fetal Bovine Serum \\
\hline NRQ & Normalized Relative Quantity \\
\hline ACTB & Actin Beta \\
\hline GAPDH & Glyceraldehyde-3-phosphate Dehydrogenase \\
\hline$R P L 13 A$ & Ribosomal Protein L13a \\
\hline PGK1 & Phosphoglycerate Kinase 1 \\
\hline HSP90AB1 & Heat Shock Protein 90 Alpha family Class B member 1 \\
\hline RNA18S & RNA, 18S ribosomal \\
\hline RNA28S & RNA, 28S ribosomal \\
\hline PUM1 & Pumilio RNA Binding family member \\
\hline CCSER2 & Coiled-Coil Serine Rich protein 2 \\
\hline$H N R N P L$ & Heterogeneous Nuclear Ribonucleoprotein L \\
\hline PCBP1 & Poly(rC) Binding protein 1 \\
\hline SF3A1 & Splicing factor $3 a$ subunit 1 \\
\hline DAD1 & Defender against cell death 1 \\
\hline PSMB4 & Proteasome $20 S$ subunit beta 4 \\
\hline$B S G$ & Basigin (OK blood group) \\
\hline TUBA1B & Tubulin alpha $1 \mathrm{~b}$ \\
\hline
\end{tabular}




$\begin{array}{ll}\text { RBX1 } & \text { Ring-Box } 1 \\ \text { CFL1 } & \text { Cofilin 1 } \\ \text { UBC } & \text { Ubiquitin C } \\ \text { PFN1 } & \text { Profilin 1 } \\ \text { EIF5A } & \text { Eukaryotic translation initiation factor } 5 \mathrm{~A} \\ \text { TPT1 } & \text { Tumor protein, translationally controlled 1 } \\ \text { NACA } & \text { Nascent polypeptide associated complex subunit alpha } \\ \text { PPIA } & \text { Peptidylprolyl isomerase A } \\ \text { GABARAP } & \text { GABA type A receptor associated protein } \\ \text { AURKA } & \text { Aurora Kinase A } \\ \text { BUB1 } & \text { BUB1 mitotic checkpoint serine/ threonine kinase } \\ \text { SNA11 } & \text { Snail family transcriptional repressor 1 }\end{array}$

\section{Declarations}

a. Funding: The present study was funded by Riga Stradiņš University (RSU) Project Nb.5-1/252/2020.

b. Competing Interests: The authors declare no competing interests in the present study. Further, neither funders nor the funding institution had a role in the design of the study; in the collection, analysis, or interpretation of data; in the writing of the manuscript, or in the decision to publish the results.

c. Ethical Approval: Not Applicable

d. Consent to Participate: Not Applicable

e. Consent for Publication: Not Applicable

f. Availability of Data and Materials: The full TCGA dataset (after processing and ranking for HER2-E subtype) is available as Appendix 2. The RT-qPCR raw datasets and metadata analyzed are available from corresponding author upon reasonable request.

g. Code Availability: The full code for R based TCGAbiolinks used to access TCGA data in the present study is available from the corresponding author upon reasonable request. Alternatively, refer to the following online help resources (to personalize the code):

1)https://bioconductor.riken.jp/packages/3.3/bioc/vignettes/TCGAbiolinks/inst/doc/tcgaBiolinks.html (Last accessed October 2020)

2)https://bioconductor.org/packages/release/bioc/vignettes/TCGAbiolinks/inst/doc/download_prepare.html (Last accessed October 2020) 
h. Author's Contributions: NJ and IC conceptualized the study while IC, IM, DN and NJ were responsible for methodology. Transcriptomic data and statistical analysis were done by NJ. Data curation was done by $\mathrm{NJ}$ and IM. Validation of the study protocol and results was done by VP, IC, DN, IM, and NJ. Visualization was done by NJ and VP while project supervision and funding acquisition was done by IC. Investigations, coding, and validation were done by NJ. Original draft was prepared by NJ and IC while revisions and final review was done by VP, DN, IC, IM, and NJ. All authors have read and approved the final manuscript for publication.

i. Acknowledgment: We are extremely grateful and thankful to our colleagues in the Latvian Biomedical Research and Study Centre (LV-BMC) for their unconditional support in providing the Viia7 platform for performing the RT-qPCR reactions.

j. Authors' Information: All Authors (NJ, IM, DN, VP and IC) are affiliated with the Laboratory of Molecular Genetics, Institute of Oncology, Riga Stradiņš University, Dzirciema street 16, Riga, Latvia LV-1007.

\section{References}

1. Bustin SA. Real-time, fluorescence-based quantitative PCR: a snapshot of current procedures and preferences. Expert Rev Mol Diagn. 2005 Jul;5(4):493-8. doi: 10.1586/14737159.5.4.493. PMID: 16013967.

2. Bustin SA, Nolan T. Pitfalls of quantitative real-time reverse-transcription polymerase chain reaction. $J$ Biomol Tech. 2004 Sep;15(3):155-66. PMID: 15331581; PMCID: PMC2291693.

3. Remans T, Keunen E, Bex GJ, Smeets K, Vangronsveld J, Cuypers A. Reliable gene expression analysis by reverse transcription-quantitative PCR: reporting and minimizing the uncertainty in data accuracy. Plant Cell. 2014 Oct;26(10):3829-37. doi: 10.1105/tpc.114.130641. Epub 2014 Oct 31. PMID: 25361954; PMCID: PMC4247583.

4. Kubista M, Andrade JM, Bengtsson M, Forootan A, Jonák J, Lind K, Sindelka R, Sjöback R, Sjögreen B, Strömbom L, Ståhlberg A, Zoric N. The real-time polymerase chain reaction. Mol Aspects Med. 2006 AprJun;27(2-3):95-125. doi: 10.1016/j.mam.2005.12.007. Epub 2006 Feb 3. PMID: 16460794.

5. Gabert J, Beillard E, van der Velden VH, Bi W, Grimwade D, Pallisgaard N, Barbany G, Cazzaniga G, Cayuela JM, Cavé H, Pane F, Aerts JL, De Micheli D, Thirion X, Pradel V, González M, Viehmann S, Malec M, Saglio G, van Dongen JJ. Standardization and quality control studies of 'real-time' quantitative reverse transcriptase polymerase chain reaction of fusion gene transcripts for residual disease detection in leukemia - a Europe Against Cancer program. Leukemia. 2003 Dec;17(12):2318-57. doi: 10.1038/sj.leu.2403135. PMID: 14562125.

6. Wolffs P, Grage H, Hagberg 0 , Rådström P. Impact of DNA polymerases and their buffer systems on quantitative real-time PCR. J Clin Microbiol. 2004 Jan;42(1):408-11. doi: 10.1128/jcm.42.1.408411.2004. PMID: 14715792; PMCID: PMC321720.

7. Yeung AT, Holloway BP, Adams PS, Shipley GL. Evaluation of dual-labeled fluorescent DNA probe purity versus performance in real-time PCR. Biotechniques. 2004 Feb;36(2):266-70, 272, 274-5. doi: 10.2144/04362RR01. PMID: 14989091. 
8. Ginzinger DG. Gene quantification using real-time quantitative PCR: an emerging technology hits the mainstream. Exp Hematol. 2002 Jun;30(6):503-12. doi: 10.1016/s0301-472x(02)00806-8. PMID: 12063017.

9. Nolan T, Hands RE, Bustin SA. Quantification of mRNA using real-time RT-PCR. Nat Protoc. 2006;1(3):1559-82. doi: 10.1038/nprot.2006.236. PMID: 17406449.

10. Udvardi MK, Czechowski T, Scheible WR. Eleven golden rules of quantitative RT-PCR. Plant Cell. 2008 Jul;20(7):1736-7. doi: 10.1105/tpc.108.061143. Epub 2008 Jul 29. PMID: 18664613; PMCID: PMC2518243.

11. Bustin SA, Benes V, Garson JA, Hellemans J, Huggett J, Kubista M, Mueller R, Nolan T, Pfaffl MW, Shipley $\mathrm{GL}$, Vandesompele J, Wittwer CT. The MIQE guidelines: minimum information for publication of quantitative real-time PCR experiments. Clin Chem. 2009 Apr;55(4):611-22. doi:

10.1373/clinchem.2008.112797. Epub 2009 Feb 26. PMID: 19246619.

12. Baker M. qPCR: quicker and easier but don't be sloppy. Nat Methods. Feb 2011;8:207-212. Doi: 10.1038/nmeth0311-207.

13. Taylor S, Wakem M, Dijkman G, Alsarraj M, Nguyen M. A practical approach to RT-qPCR-Publishing data that conform to the MIQE guidelines. Methods. 2010 Apr;50(4):S1-5. doi: 10.1016/j.ymeth.2010.01.005. PMID: 20215014.

14. Huggett J, Dheda K, Bustin S, Zumla A. Real-time RT-PCR normalisation; strategies and considerations. Genes Immun. 2005 Jun;6(4):279-84. doi: 10.1038/sj.gene.6364190. PMID: 15815687.

15. Vandesompele J., Kubista M., Pfaffl M.W. (2009). Reference gene validation software for improved normalization. In Real-Time PCR: Current Technology and Applications, J. Logan, K. Edwards, and N. Saunders, eds (Poole, UK: Caister Academic Press), pp. 47-64.

16. Bustin SA, Benes V, Garson J, Hellemans J, Huggett J, Kubista M, Mueller R, Nolan T, Pfaffl MW et al. The need for transparency and good practices in the qPCR literature. Nat Methods. 2013 Nov;10(11):1063-7. doi: 10.1038/nmeth.2697. PMID: 24173381.

17. Vandesompele J, De Preter K, Pattyn F, Poppe B, Van Roy N, De Paepe A, Speleman F. Accurate normalization of real-time quantitative RT-PCR data by geometric averaging of multiple internal control genes. Genome Biol. 2002 Jun 18;3(7):RESEARCH0034. doi: 10.1186/gb-2002-3-7-research0034. Epub 2002 Jun 18. PMID: 12184808; PMCID: PMC126239.

18. Thellin O, Zorzi W, Lakaye B, De Borman B, Coumans B, Hennen G, Grisar T, Igout A, Heinen E. Housekeeping genes as internal standards: use and limits. J Biotechnol. 1999 Oct 8;75(2-3):291-5. doi: 10.1016/s0168-1656(99)00163-7. PMID: 10617337.

19. Lee PD, Sladek R, Greenwood CM, Hudson TJ. Control genes and variability: absence of ubiquitous reference transcripts in diverse mammalian expression studies. Genome Res. 2002 Feb;12(2):292-7. doi: 10.1101/gr.217802. PMID: 11827948; PMCID: PMC155273.

20. Barber RD, Harmer DW, Coleman RA, Clark BJ. GAPDH as a housekeeping gene: analysis of GAPDH mRNA expression in a panel of 72 human tissues. Physiol Genomics. 2005 May 11;21(3):389-95. doi: 10.1152/physiolgenomics.00025.2005. Epub 2005 Mar 15. PMID: 15769908. 
21. Ghani M, Sato C, Rogaeva E. Segmental duplications in genome-wide significant loci and housekeeping genes; warning for GAPDH and ACTB. Neurobiol Aging. 2013 Jun;34(6):1710.e1-4. doi:

10.1016/j.neurobiolaging.2012.11.006. Epub 2012 Dec 11. PMID: 23238109.

22. Olsvik PA, Søfteland L, Lie KK. Selection of reference genes for qRT-PCR examination of wild populations of Atlantic cod Gadus morhua. BMC Res Notes. 2008 Jul 16;1:47. doi: 10.1186/1756-0500-1-47. Erratum in: BMC Res Notes. 2011 Oct 27;4:456. PMID: 18710500; PMCID: PMC2527504.

23. Zhu J, He F, Song S, Wang J, Yu J. How many human genes can be defined as housekeeping with current expression data? BMC Genomics. 2008 Apr 16;9:172. doi: 10.1186/1471-2164-9-172. PMID: 18416810; PMCID: PMC2396180.

24. Velculescu VE, Madden SL, Zhang L, Lash AE, Yu J, Rago C, Lal A, Wang CJ, Beaudry GA, Ciriello KM, Cook BP, Dufault MR, Ferguson AT, Gao Y, He TC, Hermeking H, Hiraldo SK, Hwang PM, Lopez MA, Luderer HF, Mathews B, Petroziello JM, Polyak K, Zawel L, Kinzler KW, et al. Analysis of human transcriptomes. Nat Genet. 1999 Dec;23(4):387-8. doi: 10.1038/70487. PMID: 10581018.

25. Eisenberg E, Levanon EY. Human housekeeping genes are compact. Trends Genet. 2003 Jul;19(7):362-5. doi: 10.1016/S0168-9525(03)00140-9. PMID: 12850439.

26. Morse DL, Carroll D, Weberg L, Borgstrom MC, Ranger-Moore J, Gillies RJ. Determining suitable internal standards for mRNA quantification of increasing cancer progression in human breast cells by real-time reverse transcriptase polymerase chain reaction. Anal Biochem. 2005 Jul 1;342(1):69-77. doi:

10.1016/j.ab.2005.03.034. Epub 2005 Apr 12. PMID: 15958182.

27. de Jonge HJ, Fehrmann RS, de Bont ES, Hofstra RM, Gerbens F, Kamps WA, de Vries EG, van der Zee AG, te Meerman GJ, ter Elst A. Evidence based selection of housekeeping genes. PLoS One. 2007 Sep 19;2(9):e898. doi: 10.1371/journal.pone.0000898. PMID: 17878933; PMCID: PMC1976390.

28. Lyng MB, Laenkholm AV, Pallisgaard N, Ditzel HJ. Identification of genes for normalization of real-time RT-PCR data in breast carcinomas. BMC Cancer. 2008 Jan 22;8:20. doi: 10.1186/1471-2407-8-20. PMID: 18211679; PMCID: PMC2248196.

29. Gur-Dedeoglu B, Konu O, Bozkurt B, Ergul G, Seckin S, Yulug IG. Identification of endogenous reference genes for qRT-PCR analysis in normal matched breast tumor tissues. Oncol Res. 2009;17(8):353-65. doi: 10.3727/096504009788428460. PMID: 19544972.

30. Lemma S, Avnet S, Salerno M, Chano T, Baldini N. Identification and Validation of Housekeeping Genes for Gene Expression Analysis of Cancer Stem Cells. PLoS One. 2016 Feb 19;11(2):e0149481. doi: 10.1371/journal.pone.0149481. PMID: 26894994; PMCID: PMC4760967.

31. Jacob F, Guertler R, Naim S, Nixdorf S, Fedier A, Hacker NF, Heinzelmann-Schwarz V. Careful selection of reference genes is required for reliable performance of RT-qPCR in human normal and cancer cell lines. PLoS One. 2013;8(3):e59180. doi: 10.1371/journal.pone.0059180. Epub 2013 Mar 15. PMID: 23554992; PMCID: PMC3598660.

32. Maltseva DV, Khaustova NA, Fedotov NN, Matveeva EO, Lebedev AE, Shkurnikov MU, Galatenko VV, Schumacher U, Tonevitsky AG. High-throughput identification of reference genes for research and clinical RT-qPCR analysis of breast cancer samples. J Clin Bioinforma. 2013 Jul 22;3(1):13. doi: 10.1186/2043-9113-3-13. PMID: 23876162; PMCID: PMC3726509. 
33. Kılıç Y, Çelebiler AÇ, Sakızıı M. Selecting housekeeping genes as references for the normalization of quantitative PCR data in breast cancer. Clin Transl Oncol. 2014 Feb;16(2):184-90. doi: 10.1007/s12094013-1058-5. Epub 2013 May 30. PMID: 23720140.

34. Liu LL, Zhao H, Ma TF, Ge F, Chen CS, Zhang YP. Identification of valid reference genes for the normalization of RT-qPCR expression studies in human breast cancer cell lines treated with and without transient transfection. PLoS One. 2015 Jan 24;10(1):e0117058. doi: 10.1371/journal.pone.0117058. PMID: 25617865; PMCID: PMC4305315.

35. Tilli TM, Castro Cda S, Tuszynski JA, Carels N. A strategy to identify housekeeping genes suitable for analysis in breast cancer diseases. BMC Genomics. 2016 Aug 15;17(1):639. doi: 10.1186/s12864-0162946-1. PMID: 27526934; PMCID: PMC4986254.

36. Amanda P. B. Albuquerque, Meritxell Balmaña, Celso A. Reis, Eduardo I.C. Beltrão. Identification of appropriate housekeeping genes for quantitative RT-PCR analysis in MDA-MB-231 and NCI-H460 human cancer cell lines under hypoxia and serum deprivation. Journal of Molecular and Clinical Medicine. 2018;1(3): 127-134. Doi: 10.31083/j.jmcm.2018.03.001.

37. Jo J, Choi S, Oh J, Lee SG, Choi SY, Kim KK, Park C. Conventionally used reference genes are not outstanding for normalization of gene expression in human cancer research. BMC Bioinformatics. 2019 May 29;20(Suppl 10):245. doi: 10.1186/s12859-019-2809-2. PMID: 31138119; PMCID: PMC6538551.

38. Krasnov GS, Kudryavtseva AV, Snezhkina AV, Lakunina VA, Beniaminov AD, Melnikova NV, Dmitriev AA. Pan-Cancer Analysis of TCGA Data Revealed Promising Reference Genes for qPCR Normalization. Front Genet. 2019 Mar 1;10:97. doi: 10.3389/fgene.2019.00097. PMID: 30881377; PMCID: PMC6406071.

39. Bray F, Ferlay J, Soerjomataram I, Siegel RL, Torre LA, Jemal A. Global cancer statistics 2018: GLOBOCAN estimates of incidence and mortality worldwide for 36 cancers in 185 countries. CA Cancer J Clin. 2018 Nov;68(6):394-424. doi: 10.3322/caac.21492. Epub 2018 Sep 12. Erratum in: CA Cancer J Clin. 2020 Jul;70(4):313. PMID: 30207593.

40. Heer E, Harper A, Escandor N, Sung H, McCormack V, Fidler-Benaoudia MM. Global burden and trends in premenopausal and postmenopausal breast cancer: a population-based study. Lancet Glob Health. 2020 Aug;8(8):e1027-e1037. doi: 10.1016/S2214-109X(20)30215-1. PMID: 32710860.

41. Parker JS, Mullins M, Cheang MC, Leung S, Voduc D, Vickery T, Davies S, Fauron C, He X, Hu Z, Quackenbush JF, Stijleman IJ, Palazzo J, Marron JS, Nobel AB, Mardis E, Nielsen TO, Ellis MJ, Perou CM, Bernard PS. Supervised risk predictor of breast cancer based on intrinsic subtypes. J Clin Oncol. 2009 Mar 10;27(8):1160-7. doi: 10.1200/JC0.2008.18.1370. Epub 2009 Feb 9. PMID: 19204204; PMCID: PMC2667820.

42. Dowsett M, Sestak I, Lopez-Knowles E, Sidhu K, Dunbier AK, Cowens JW, Ferree S, Storhoff J, Schaper C, Cuzick J. Comparison of PAM50 risk of recurrence score with oncotype DX and IHC4 for predicting risk of distant recurrence after endocrine therapy. J Clin Oncol. 2013 Aug 1;31(22):2783-90. doi: 10.1200/JCO.2012.46.1558. Epub 2013 Jul 1. PMID: 23816962.

43. Gnant M, Filipits M, Greil R, Stoeger H, Rudas M, Bago-Horvath Z, Mlineritsch B, Kwasny W, Knauer M, Singer C, Jakesz R, Dubsky P, Fitzal F, Bartsch R, Steger G, Balic M, Ressler S, Cowens JW, Storhoff J, Ferree S, Schaper C, Liu S, Fesl C, Nielsen TO; Austrian Breast and Colorectal Cancer Study Group. Predicting distant recurrence in receptor-positive breast cancer patients with limited clinicopathological 
risk: using the PAM50 Risk of Recurrence score in 1478 postmenopausal patients of the ABCSG-8 trial treated with adjuvant endocrine therapy alone. Ann Oncol. 2014 Feb;25(2):339-45. doi:

10.1093/annonc/mdt494. Epub 2013 Dec 16. PMID: 24347518.

44. Ferrari A, Vincent-Salomon A, Pivot X, Sertier AS, Thomas E, Tonon L, Boyault S, Mulugeta E, et al. A whole-genome sequence and transcriptome perspective on HER2-positive breast cancers. Nat Commun. 2016 Jul 13;7:12222. doi: 10.1038/ncomms12222. PMID: 27406316; PMCID: PMC4947184.

45. Cejalvo JM, Pascual T, Fernández-Martínez A, Brasó-Maristany F, Gomis RR, Perou CM, Muñoz M, Prat A. Clinical implications of the non-luminal intrinsic subtypes in hormone receptor-positive breast cancer. Cancer Treat Rev. 2018 Jun;67:63-70. doi: 10.1016/j.ctrv.2018.04.015. Epub 2018 May 7. PMID: 29763779.

46. SK-BR-3: Human Breast Cancer Cell Line (ATCC HTB-30) [Internet]. Memorial Sloan Kettering Cancer Center. Available from: https://www.mskcc.org/research-advantage/support/technology/tangiblematerial/human-breast-cell-line-sk-br-3. Last accessed November 2020.

47. Paraic A Kenny, Genee Y Lee, Connie A Myers, Richard M Neve, Jeremy R Semeiks, Paul T Spellman, Katrin Lorenz, Eva H Lee, Mary Helen Barcellos-Hoff, Ole W Petersen, Joe W Gray, Mina J Bissell. The morphologies of breast cancer cell lines in three-dimensional assays correlate with their profiles of gene expression. Molecular Oncology,2007 Jun;1(1):84-96.

48. Kao J, Salari K, Bocanegra M, Choi YL, Girard L, Gandhi J, Kwei KA, Hernandez-Boussard T, Wang P, Gazdar AF, Minna JD, Pollack JR. Molecular profiling of breast cancer cell lines defines relevant tumor models and provides a resource for cancer gene discovery. PLoS One. 2009 Jul 3;4(7):e6146. doi: 10.1371/journal.pone.0006146. PMID: 19582160; PMCID: PMC2702084.

49. Marcotte R, Sayad A, Brown KR, Sanchez-Garcia F, Reimand J, Haider M, Virtanen C, Bradner JE, Bader GD, Mills GB, Pe'er D, Moffat J, Neel BG. Functional Genomic Landscape of Human Breast Cancer Drivers, Vulnerabilities, and Resistance. Cell. 2016 Jan 14;164(1-2):293-309. doi: 10.1016/j.cell.2015.11.062. PMID: 26771497; PMCID: PMC4724865.

50. Siddiqui RA, Harvey KA, Walker C, Altenburg J, Xu Z, Terry C, Camarillo I, Jones-Hall Y, Mariash C. Characterization of synergistic anti-cancer effects of docosahexaenoic acid and curcumin on DMBAinduced mammary tumorigenesis in mice. BMC Cancer. 2013 Sep 13;13:418. doi: 10.1186/1471-240713-418. PMID: 24034496; PMCID: PMC3848456.

51. Brasó-Maristany F, Griguolo G, Pascual T, Paré L, Nuciforo P, Llombart-Cussac A, et al. Phenotypic changes of HER2-positive breast cancer during and after dual HER2 blockade. Nat Commun. 2020 Jan 20;11(1):385. doi: 10.1038/s41467-019-14111-3. PMID: 31959756; PMCID: PMC6971277.

52. Colaprico A, Silva TC, Olsen C, Garofano L, Cava C, Garolini D, Sabedot TS, Malta TM, Pagnotta SM, Castiglioni I, Ceccarelli M, Bontempi G, Noushmehr H. TCGAbiolinks: an R/Bioconductor package for integrative analysis of TCGA data. Nucleic Acids Res. 2016 May 5;44(8):e71. doi: 10.1093/nar/gkv1507. Epub 2015 Dec 23. PMID: 26704973; PMCID: PMC4856967.

53. Silva TC, Colaprico A, Olsen C, D'Angelo F, Bontempi G, Ceccarelli M, Noushmehr H. TCGA Workflow: Analyze cancer genomics and epigenomics data using Bioconductor packages. F1000Res. 2016 Jun 29;5:1542. doi: 10.12688/f1000research.8923.2. PMID: 28232861; PMCID: PMC5302158. 
54. Mounir M, Lucchetta M, Silva TC, Olsen C, Bontempi G, Chen X, Noushmehr H, Colaprico A, Papaleo E. New functionalities in the TCGAbiolinks package for the study and integration of cancer data from GDC and GTEx. PLoS Comput Biol. 2019 Mar 5;15(3):e1006701. doi: 10.1371/journal.pcbi.1006701. PMID: 30835723; PMCID: PMC6420023.

55. Ashburner M, Ball CA, Blake JA, Botstein D, Butler H, Cherry JM, Davis AP, Dolinski K, Dwight SS, Eppig JT, Harris MA, Hill DP, Issel-Tarver L, Kasarskis A, Lewis S, Matese JC, Richardson JE, Ringwald M, Rubin GM, Sherlock G. Gene ontology: tool for the unification of biology. The Gene Ontology Consortium. Nat Genet. 2000 May;25(1):25-9. doi: 10.1038/75556. PMID: 10802651; PMCID: PMC3037419.

56. Gene Ontology Consortium. The Gene Ontology resource: enriching a GOld mine. Nucleic Acids Res. 2021 Jan 8;49(D1):D325-D334. doi: 10.1093/nar/gkaa1113. PMID: 33290552; PMCID: PMC7779012.

57. Mi H, Muruganujan A, Ebert D, Huang X, Thomas PD. PANTHER version 14: more genomes, a new PANTHER GO-slim and improvements in enrichment analysis tools. Nucleic Acids Res. 2019 Jan 8;47(D1):D419-D426. doi: 10.1093/nar/gky1038. PMID: 30407594; PMCID: PMC6323939.

58. Mi H, Muruganujan A, Casagrande JT, Thomas PD. Large-scale gene function analysis with the PANTHER classification system. Nat Protoc. 2013 Aug;8(8):1551-66. doi: 10.1038/nprot.2013.092. Epub 2013 Jul 18. PMID: 23868073; PMCID: PMC6519453.

59. Dalmer TRA, Clugston RD. Gene ontology enrichment analysis of congenital diaphragmatic herniaassociated genes. Pediatr Res. 2019 Jan;85(1):13-19. doi: 10.1038/s41390-018-0192-8. Epub 2018 Sep 25. Erratum in: Pediatr Res. 2019 Aug 14;: PMID: 30287891; PMCID: PMC6760551.

60. Pirsko, V.; Cakstina, I.; Priedite, M.; Dortane, R.; Feldmane, L.; Nakazawa-Miklasevica, M.; Daneberga, Z.; Gardovskis, J.; Miklasevics, E. An Effect of Culture Media on Epithelial Differentiation Markers in Breast Cancer Cell Lines MCF7, MDA-MB-436 and SkBr3. Medicina 2018, 54, 11. https://doi.org/10.3390/medicina54020011.

61. Untergasser A, Nijveen H, Rao X, Bisseling T, Geurts R, Leunissen JA. Primer3Plus, an enhanced web interface to Primer3. Nucleic Acids Res. 2007 Jul;35(Web Server issue):W71-4. doi: 10.1093/nar/gkm306. Epub 2007 May 7. PMID: 17485472; PMCID: PMC1933133.

62. Jain N, Nitisa D, Pirsko V, Cakstina I. Selecting suitable reference genes for qPCR normalization: a comprehensive analysis in MCF-7 breast cancer cell line. BMC Mol Cell Biol. 2020 Sep 25;21(1):68. doi: 10.1186/s12860-020-00313-x. PMID: 32977762; PMCID: PMC7519550.

63. Andersen CL, Jensen JL, Ørntoft TF. Normalization of real-time quantitative reverse transcription-PCR data: a model-based variance estimation approach to identify genes suited for normalization, applied to bladder and colon cancer data sets. Cancer Res. 2004 Aug 1;64(15):5245-50. doi: 10.1158/00085472.CAN-04-0496. PMID: 15289330.

64. Pfaffl MW, Tichopad A, Prgomet C, Neuvians TP. Determination of stable housekeeping genes, differentially regulated target genes and sample integrity: BestKeeper-Excel-based tool using pair-wise correlations. Biotechnol Lett. 2004 Mar;26(6):509-15. doi: 10.1023/b:bile.0000019559.84305.47. PMID: 15127793.

65. Silver N, Best S, Jiang J, Thein SL. Selection of housekeeping genes for gene expression studies in human reticulocytes using real-time PCR. BMC Mol Biol. 2006 Oct 6;7:33. doi: 10.1186/1471-2199-7-33. 
PMID: 17026756; PMCID: PMC1609175.

66. Xie F, Xiao P, Chen D, Xu L, Zhang B. miRDeepFinder: a miRNA analysis tool for deep sequencing of plant small RNAs. Plant Mol Biol. 2012 Jan 31. doi: 10.1007/s11103-012-9885-2. Epub ahead of print. PMID: 22290409.

67. Livak KJ, Schmittgen TD. Analysis of relative gene expression data using real-time quantitative PCR and the 2(-Delta Delta C(T)) Method. Methods. 2001 Dec;25(4):402-8. doi: 10.1006/meth.2001.1262. PMID: 11846609.

68. Pfaffl MW. A new mathematical model for relative quantification in real-time RT-PCR. Nucleic Acids Res. 2001 May 1;29(9):e45. doi: 10.1093/nar/29.9.e45. PMID: 11328886; PMCID: PMC55695

69. Hellemans J, Mortier G, De Paepe A, Speleman F, Vandesompele J. qBase relative quantification framework and software for management and automated analysis of real-time quantitative PCR data. Genome Biol. 2007;8(2):R19. doi: 10.1186/gb-2007-8-2-r19. PMID: 17291332; PMCID: PMC1852402.

70. D’haene B., Hellemans J. The importance of quality control during qPCR data analyis. Int. Drug Discov. 2010: 18-24.

71. Cooper LA, Demicco EG, Saltz JH, Powell RT, Rao A, Lazar AJ. PanCancer insights from The Cancer Genome Atlas: the pathologist's perspective. J Pathol. 2018;244(5):512-24.

https://doi.org/10.1002/path.5028.

72. Esquivel-Velázquez M, Ostoa-Saloma P, Palacios-Arreola MI, Nava-Castro KE, Castro Jl, Morales-Montor J. The role of cytokines in breast cancer development and progression. J Interferon Cytokine Res. 2015 Jan;35(1):1-16. doi: 10.1089/jir.2014.0026. Epub 2014 Jul 28. PMID: 25068787; PMCID: PMC4291218.

73. Joshi A, Cao D. TGF-beta signaling, tumor microenvironment and tumor progression: the butterfly effect. Front Biosci (Landmark Ed). 2010 Jan 1;15:180-94. doi: 10.2741/3614. PMID: 20036814.

74. Vincent T, Neve EP, Johnson JR, Kukalev A, Rojo F, Albanell J, Pietras K, Virtanen I, Philipson L, Leopold PL, Crystal RG, de Herreros AG, Moustakas A, Pettersson RF, Fuxe J. A SNAIL 1-SMAD3/4 transcriptional repressor complex promotes TGF-beta mediated epithelial-mesenchymal transition. Nat Cell Biol. 2009 Aug;11(8):943-50. doi: 10.1038/ncb1905. Epub 2009 Jul 13. PMID: 19597490; PMCID: PMC3769970.

75. Honma S, Shimodaira K, Shimizu Y, Tsuchiya N, Saito H, Yanaihara T, Okai T. The influence of inflammatory cytokines on estrogen production and cell proliferation in human breast cancer cells. Endocr J. 2002 Jun;49(3):371-7. doi: 10.1507/endocrj.49.371. PMID: 12201223.

76. Horiuchi K, Mishima K, Ohsawa M, Aozasa K. Carcinoma of stomach and breast with lymphoid stroma: localisation of Epstein-Barr virus. J Clin Pathol. 1994 Jun;47(6):538-40. doi: 10.1136/jcp.47.6.538. PMID: 8063937; PMCID: PMC494746.

77. Di Lonardo A, Venuti A, Marcante ML. Human papillomavirus in breast cancer. Breast Cancer Res Treat. 1992;21(2):95-100. doi: 10.1007/BF01836955. PMID: 1320958.

78. Buehring G.C., Shen H.M., Jensen H.M., Block G. Bovine leukemia virus infection is significantly associated with risk of breast cancer. Proc. Amer. Assoc. Cancer Res. 2007;48:1747

79. Wang Y, Holland JF, Bleiweiss IJ, Melana S, Liu X, Pelisson I, Cantarella A, Stellrecht K, Mani S, Pogo BG. Detection of mammary tumor virus env gene-like sequences in human breast cancer. Cancer Res. 1995 Nov 15;55(22):5173-9. PMID: 7585568.

Page 24/32 
80. Lawson JS, Glenn WK, Heng B, Ye Y, Tran B, Lutze-Mann L, Whitaker NJ. Koilocytes indicate a role for human papilloma virus in breast cancer. Br J Cancer. 2009 Oct 20;101(8):1351-6. doi: 10.1038/sj.bjc.6605328. Epub 2009 Sep 22. PMID: 19773762; PMCID: PMC2768439.

81. Jie Fu, Lihong Bian, Li Zhao, Zhouhuan Dong, Xin Gao, Haofei Luan, Yunjuan Sun, Haifeng Song, Identification of genes for normalization of quantitative real-time PCR data in ovarian tissues, Acta Biochimica et Biophysica Sinica, Volume 42, Issue 8, August 2010, Pages 568-574, https://doi.org/10.1093/abbs/gmq062

82. Perez, L.J., Rios, L., Trivedi, P. et al. Validation of optimal reference genes for quantitative real time PCR in muscle and adipose tissue for obesity and diabetes research. Sci Rep 7, 3612 (2017). https://doi.org/10.1038/s41598-017-03730-9

83. Bukowska, J., Stowińska, M., Cierniak, P. et al. The effect of hypoxia on the proteomic signature of pig adipose-derived stromal/stem cells (pASCs). Sci Rep 10, 20035 (2020). https://doi.org/10.1038/s41598020-76796-7

84. Sonna LA, Cullivan ML, Sheldon HK, Pratt RE, Lilly CM. Effect of hypoxia on gene expression by human hepatocytes (HepG2). Physiol Genomics. 2003 Feb 6;12(3):195-207. doi:

10.1152/physiolgenomics.00104.2002. PMID: 12464685.

85. Sanjay A, Fu J, Kreibich G. DAD1 is required for the function and the structural integrity of the oligosaccharyltransferase complex. J Biol Chem. 1998 Oct 2;273(40):26094-9. doi: 10.1074/jbc.273.40.26094. PMID: 9748289.

86. Nakashima, T., T. Sekiguchi, A. Kuraoka, K. Fukushima, Y. Shibata, S. Komiyama, T. Nishimoto. 1993. Molecular cloning of a human cDNA encoding a novel protein, DAD1, whose defect causes apoptotic cell death in hamster BHK21 cells. Mol. Cell. Biol. 13: 6367

87. Silberstein, S., P. G. Collins, D. J. Kelleher, R. Gilmore. 1995. The essential OST2 gene encodes the 16-kDa subunit of the yeast oligosaccharyltransferase, a highly conserved protein expressed in diverse eukaryotic organisms. J. Cell Biol. 131: 371

88. Tanaka K, Kondoh N, Shuda M, Matsubara O, Imazeki N, Ryo A, Wakatsuki T, Hada A, Goseki N, Igari T, Hatsuse K, Aihara T, Horiuchi S, Yamamoto N, Yamamoto M. Enhanced expression of mRNAs of antisecretory factor-1, gp96, DAD1 and CDC34 in human hepatocellular carcinomas. Biochim Biophys Acta. 2001 Apr 30;1536(1):1-12. doi: 10.1016/s0925-4439(01)00026-6. PMID: 11335099.

89. Zhang H, Hoang T, Saeed B, Ng SC. Induction of apoptosis in prostatic tumor cell line DU145 by staurosporine, a potent inhibitor of protein kinases. Prostate. 1996 Aug;29(2):69-76. doi: 10.1002/(SICI)1097-0045(199608)29:2<69::AID-PROS1>3.0.CO;2-C. PMID: 8700802.

90. Ren Y, Hao P, Dutta B, Cheow ES, Sim KH, Gan CS, Lim SK, Sze SK. Hypoxia modulates A431 cellular pathways association to tumor radioresistance and enhanced migration revealed by comprehensive proteomic and functional studies. Mol Cell Proteomics. 2013 Feb;12(2):485-98. doi: 10.1074/mcp.M112.018325. Epub 2012 Nov 30. PMID: 23204318; PMCID: PMC3567868.

91. Ding Z, Bae YH, Roy P. Molecular insights on context-specific role of profilin-1 in cell migration. Cell Adh Migr. 2012 Sep-Oct;6(5):442-9. doi: 10.4161/cam.21832. Epub 2012 Sep 1. PMID: 23076048; PMCID: PMC3496682. 
92. Witke W. The role of profilin complexes in cell motility and other cellular processes. Trends Cell Biol. 2004 Aug;14(8):461-9. doi: 10.1016/j.tcb.2004.07.003. PMID: 15308213.

93. Bae YH, Ding Z, Zou L, Wells A, Gertler F, Roy P. Loss of profilin-1 expression enhances breast cancer cell motility by Ena/VASP proteins. J Cell Physiol. 2009 May;219(2):354-64. doi: 10.1002/jcp.21677. PMID: 19115233; PMCID: PMC2990882.

94. Das T, Bae YH, Wells A, Roy P. Profilin-1 overexpression upregulates PTEN and suppresses AKT activation in breast cancer cells. J Cell Physiol. 2009 Feb;218(2):436-43. doi: 10.1002/jcp.21618. PMID: 18937284; PMCID: PMC2874249.

95. Yao, W., Ji, S., Qin, Y. et al. Profilin-1 suppresses tumorigenicity in pancreatic cancer through regulation of the SIRT3-HIF1a axis. Mol Cancer 13, 187 (2014). https://doi.org/10.1186/1476-4598-13-187

96. Roy, P., Gau, D., Bae, Y. and Ohayon, L. (2019), Breast cancer cell invasiveness is stimulated by loss of membrane interaction of actinbinding protein profilin1 via altered phosphoinositide metabolism. The FASEB Journal, 33: 488.13-488.13. https://doi.org/10.1096/fasebj.2019.33.1_supplement.488.13

97. Guan X, Chen S, Liu Y, Wang LL, Zhao Y, Zong ZH. PUM1 promotes ovarian cancer proliferation, migration and invasion. Biochem Biophys Res Commun. 2018 Feb 26;497(1):313-318. doi: 10.1016/j.bbrc.2018.02.078. Epub 2018 Feb 8. PMID: 29428722.

98. Kim JW, Kim SJ, Han SM, Paik SY, Hur SY, Kim YW, Lee JM, Namkoong SE. Increased glyceraldehyde-3phosphate dehydrogenase gene expression in human cervical cancers. Gynecol Oncol. 1998;71(2):2669. https://doi.org/10.1006/gyno.1998.5195.

99. Rondinelli RH, Epner DE, Tricoli JV. Increased glyceraldehyde-3-phosphate dehydrogenase gene expression in late pathological stage human prostate cancer. Prostate Cancer Prostatic Dis. 1997;1(2):66-72. https://doi.org/10.1038/sj.pcan.4500208.

\section{Figures}


a

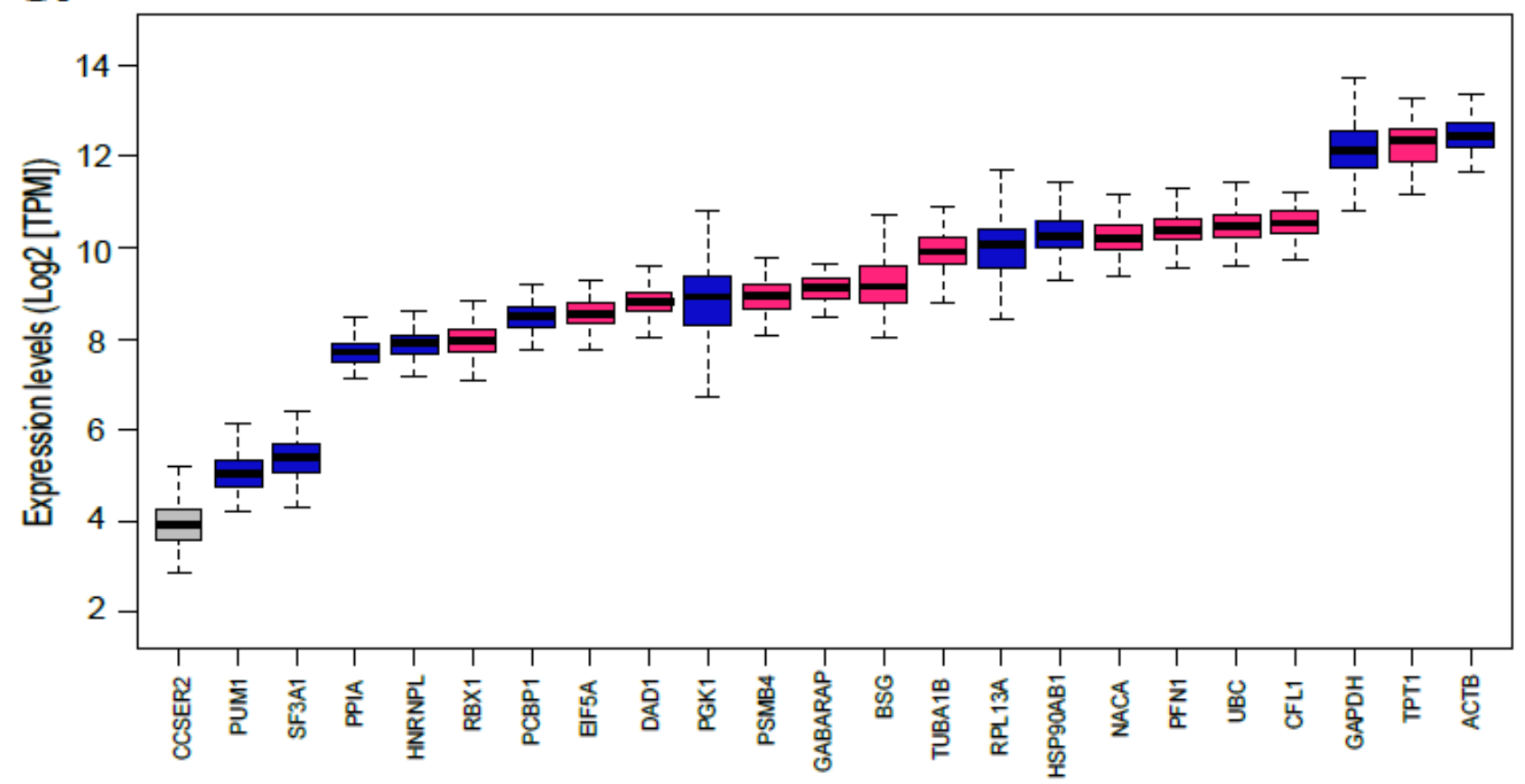

b

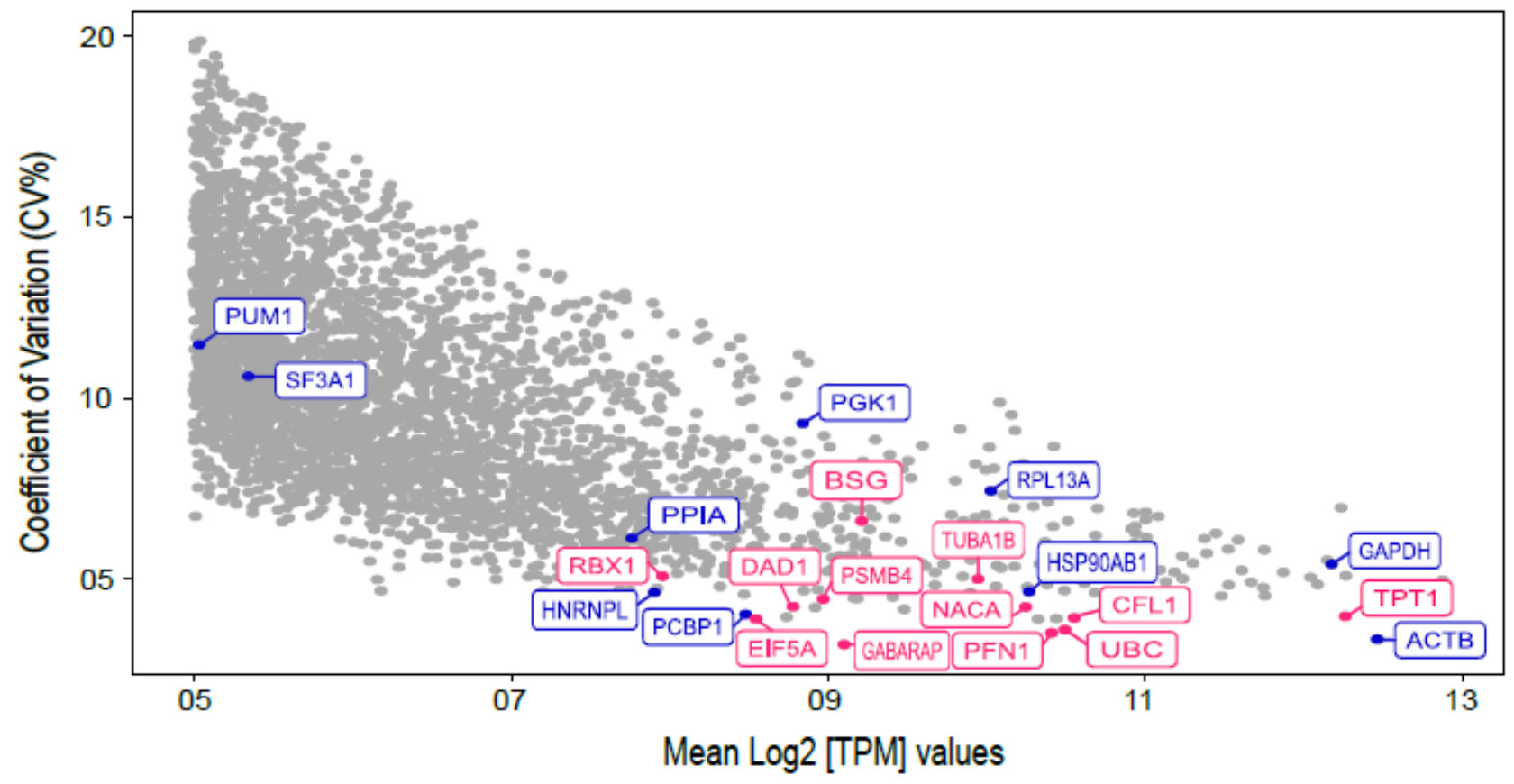

Figure 1

Ranking of the novel (pink) and conventional (blue) candidate reference genes. The rankings are based on TCGA database analysis. (a) Gene ranking based on expression levels (log2[TPM]); (b) Scatterplot showing the order of genes based on CV\% and mean log2[TPM] values. CCSER2 (grey boxplot) was retrieved as FAM190B and violated the selection criteria due to low expression levels. 


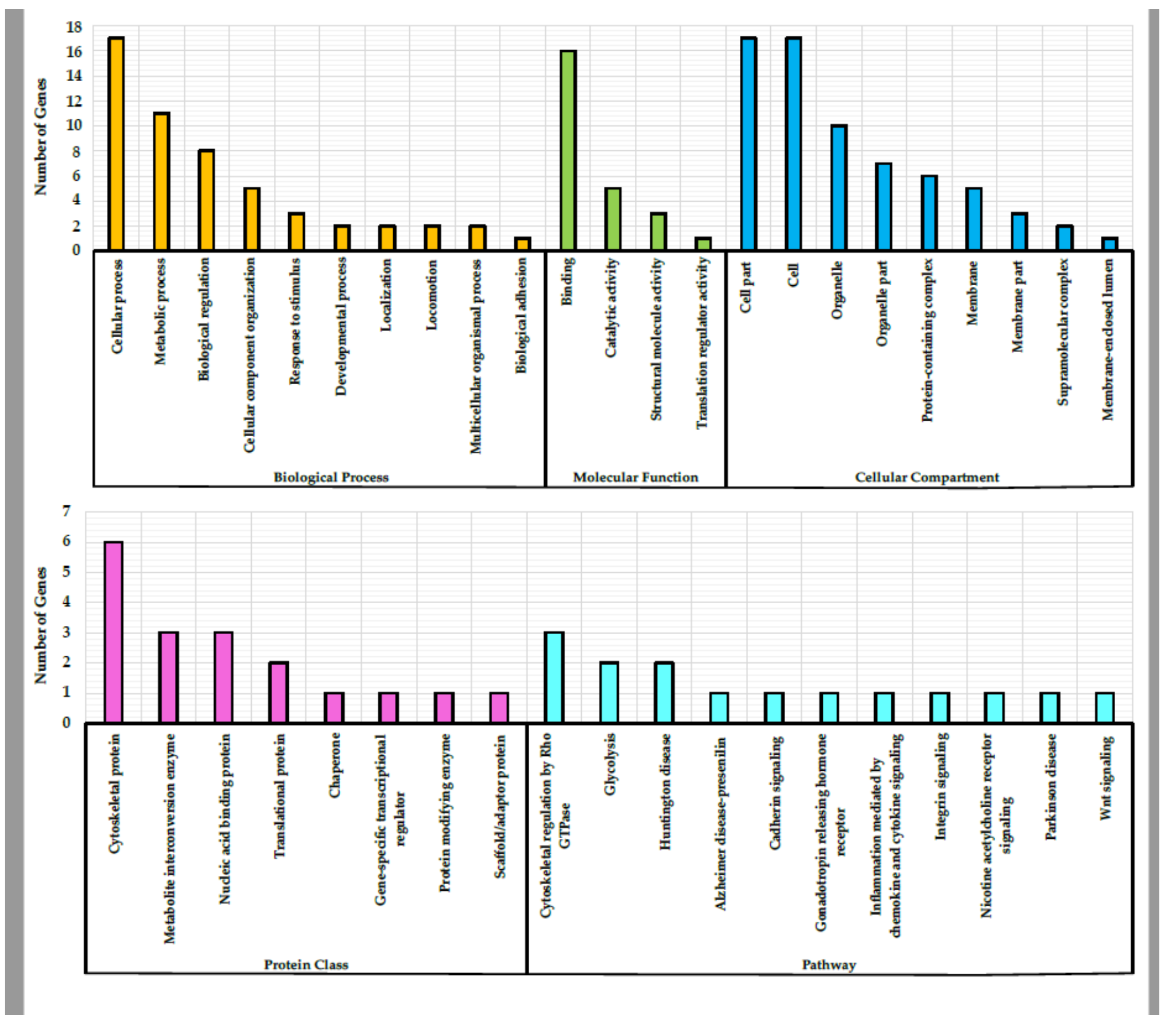

Figure 2

Grouping of the candidate reference genes according to Panther Functional Classification, which is further based on five different ontologies. 

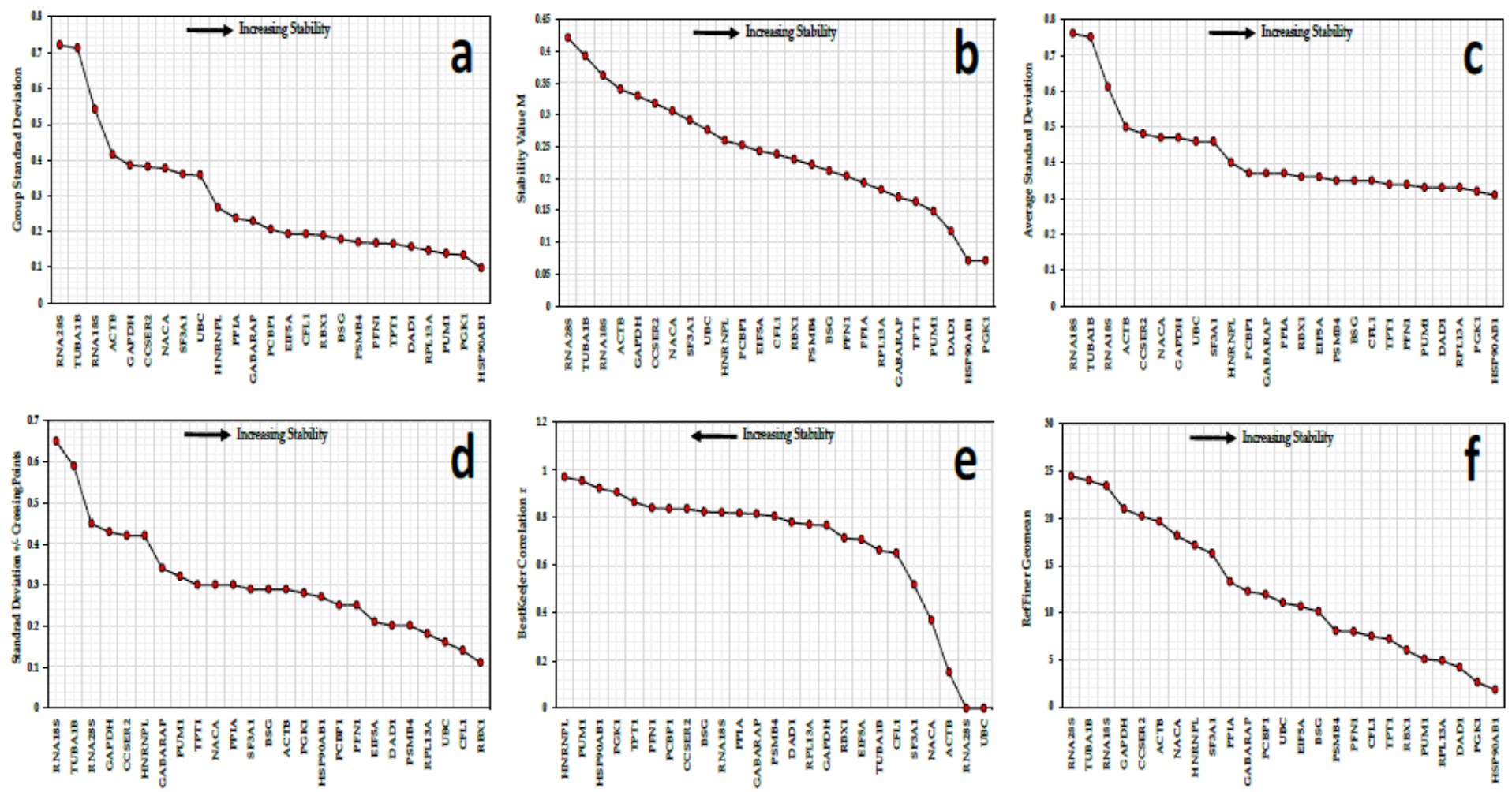

\section{Figure 3}

Ranking of candidate reference genes according to various algorithms (a) NormFinder; (b) geNorm; (c) Comparative $\Delta \mathrm{Ct}$; (d) BestKeeper; (e) Correlation with BestKeeper Index (BI) and (f) RefFinder. 


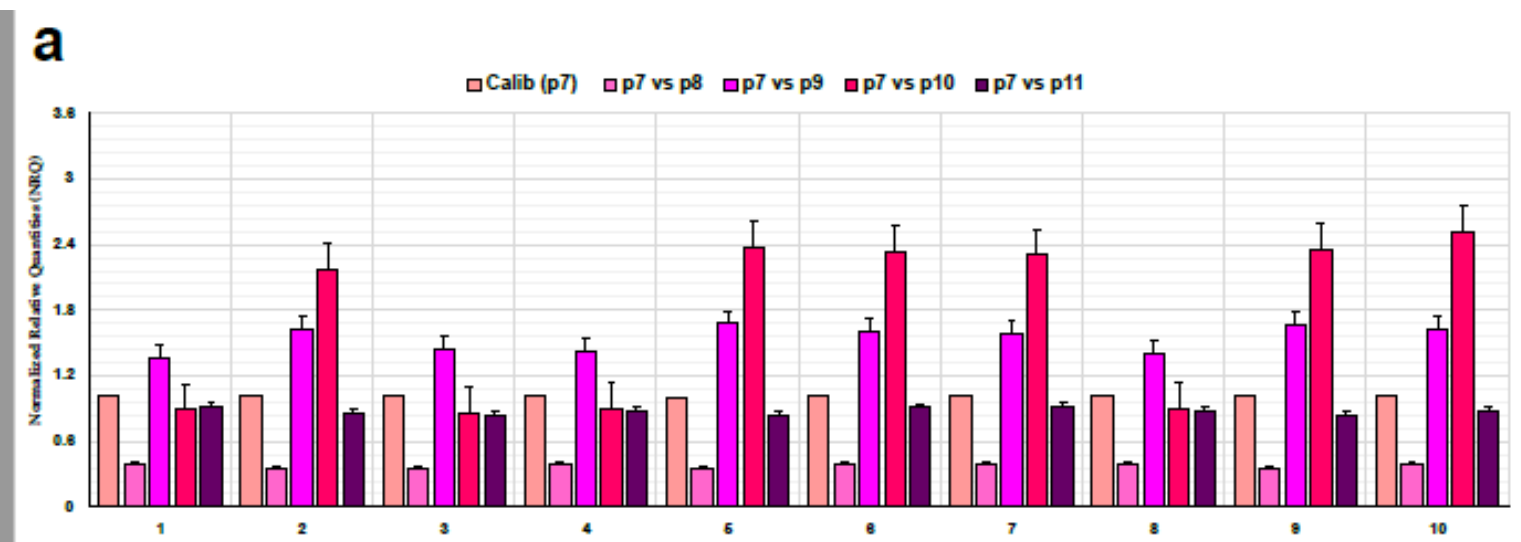

b

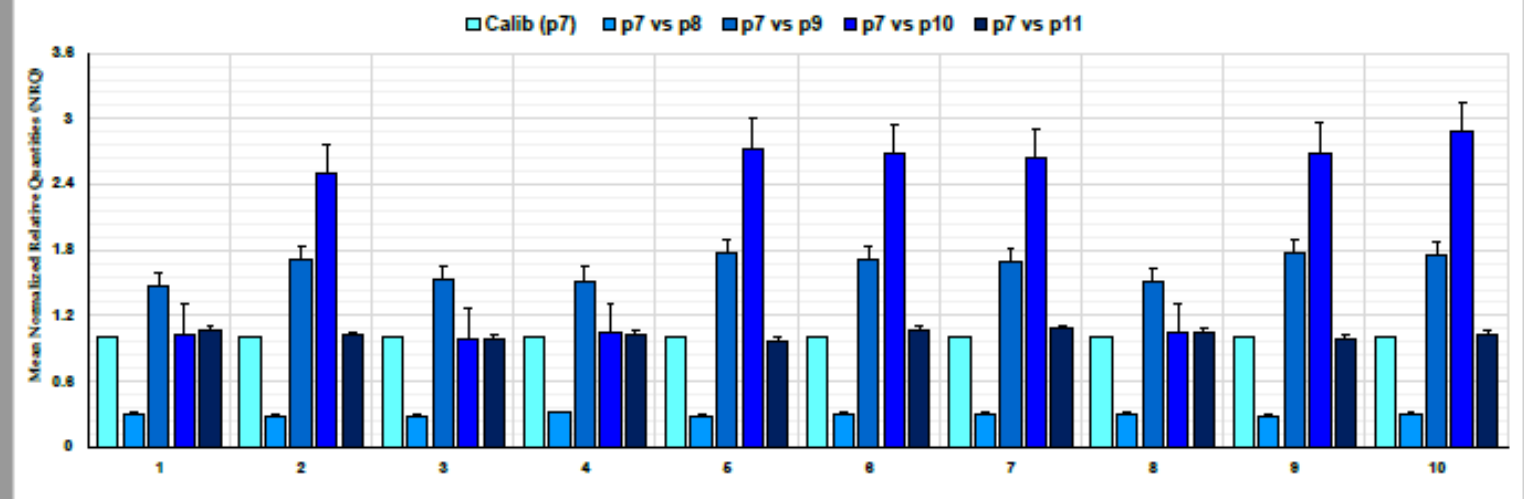

C

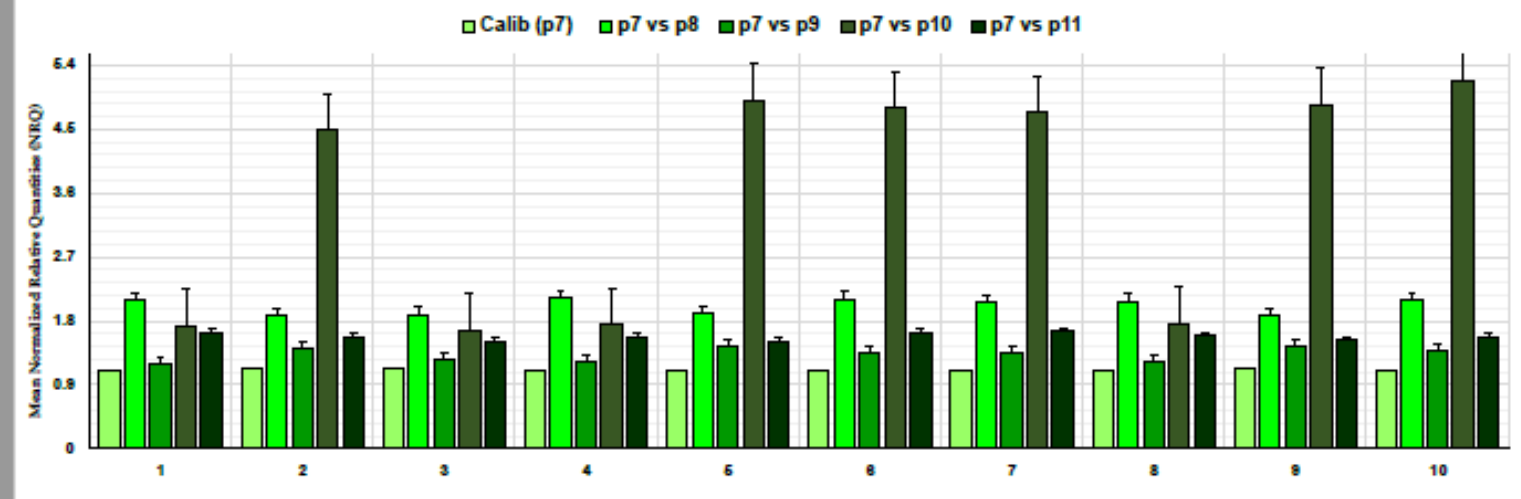

FIGURE LEGEND

\begin{tabular}{|c|c|c|c|}
\hline Code & Triplet Genes & Code & Triplet Genes \\
\hline 1 & HSP90AB1 - DAD1 - PFN1 & 6 & HSP90AB1 - PFN1 - RPL13A \\
\hline 2 & HSP90AB1 - DAD1 - RPL13A & 7 & DAD1 - PFN1 - RPL13A \\
\hline 3 & HSP90AB1 - DAD1 - PUM1 & 8 & DAD1 - PFN1 - PUM1 \\
\hline 4 & HSP90AB1 - PFN1 - PUM1 & 9 & DAD1 - RPL13A - PUM1 \\
\hline 5 & HSP90AB1 - PUM1 - RPL13A & 10 & PFN1 - RPL13A - PUM1 \\
\hline
\end{tabular}

Figure 4

Normalization of the three genes of interest (GOIs) in sequential passage experiments of SK-BR-3 cell line (S1+S2) for (a) AURKA; (b) BUB1 and (c) SNAI1. The corresponding triplet codes shown on the $x$-axis are interpreted in figure legend. Error bars indicate the standard error (S.E.). Calib (p7) stands for the calibration passage 7, i.e., the initial passage which was used as an internal experimental control to obtain normalized relative quantities (NRQ) by Pfaffl's method. 

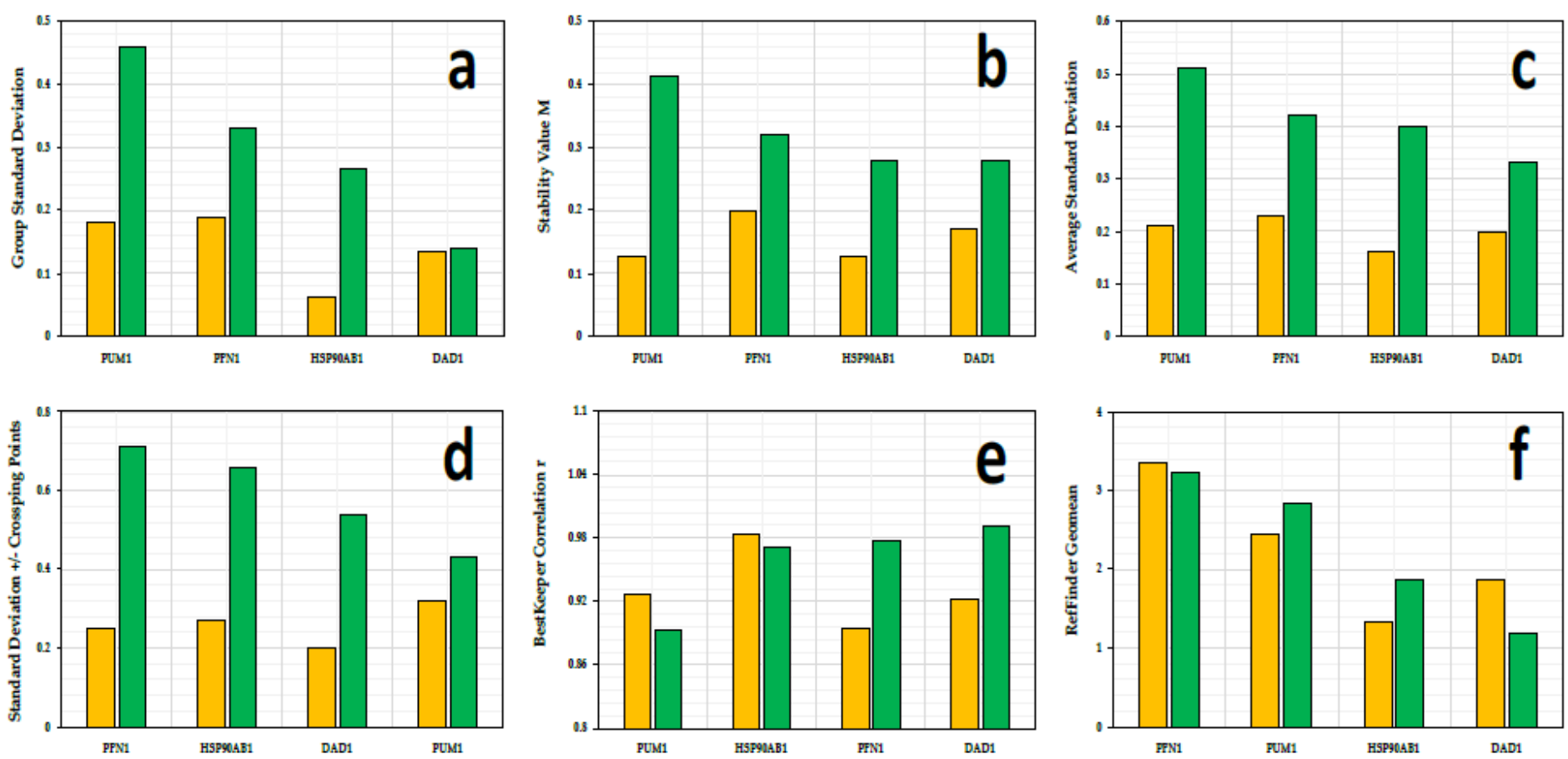

Figure 5

Ranking of the candidate reference genes according to various algorithms (a) NormFinder; (b) geNorm; (c) Comparative $\Delta \mathrm{Ct}$; (d) BestKeeper; (e) correlation with BestKeeper Index (BI) and (f) RefFinder. Yellow bars indicate the stability values for the genes in normoxia samples, while the green bars indicate the stability values for the genes in all samples (normoxia \& hypoxia). The reference genes are ranked according to the stability rankings in all samples (green bars). The stability of the reference genes in the sample pool increases from left to right for all algorithms.
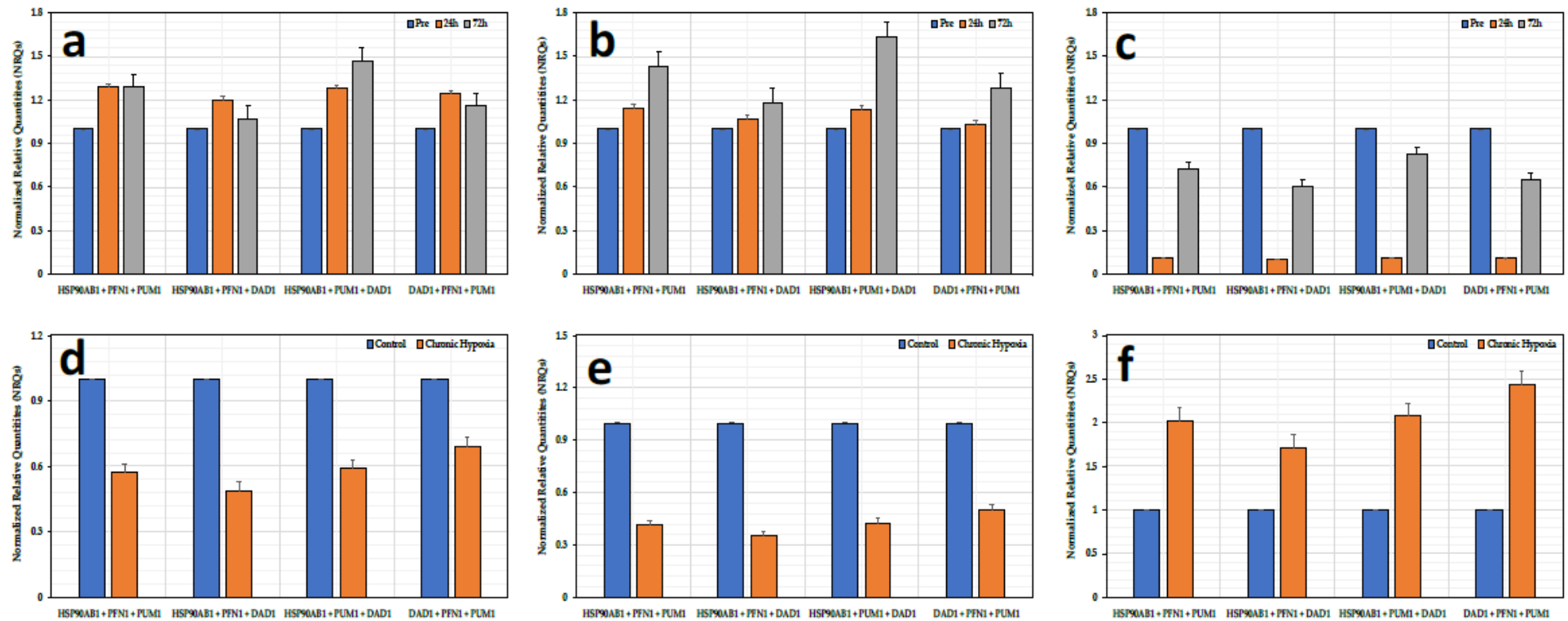

Figure 6 
Normalization (Pfaff's method) of the three genes of interest (GOIs) in SK-BR-3 cell line in acute hypoxia (a-c) and chronic hypoxia (d-f) for (a,d) AURKA; $(b, e)$ BUB1 and (c,f) SNAI1.

\section{Supplementary Files}

This is a list of supplementary files associated with this preprint. Click to download.

- Jainetal.AdditionalFile1.pdf

- Jainetal.AdditionalFile2.pdf

- Jainetal.AdditionalFile3.pdf

- Jainetal.Appendix1.pdf

- Jainetal.Appendix2.xlsx 